\title{
THE ANCESTRY OF THE RHENISH MIDDLE SIEGENIAN BRACHIOPOD FAUNA IN THE IBERIAN CHAINS AND ITS PALAEOZOOGEOGRAPHY (EARLY DEVONIAN)
}

\author{
Peter CARLS' and José Ignacio VALENZUELA-RÍOS \\ ' Institut für Geowissenschaften, Technische Universität Braunschweig. Pockels-Str. 3. \\ D-38106 Braunschweig. Germany. \\ 2 Departament de Geologia. Universitat de València. Dr. Moliner, 50. E-46100 Burjasøt, \\ València. Spain. E-mail: jose.i.valenzuela@uv.es
}

Carls, P. and Valenzuela-Ríos, J.I. 1998. The ancestry of the Rhenish Middle Siegenian brachiopod fauna in the Iberian Chains and its palaeozoogeography (Early Devonian). [El origen de la fauna de braquiópodos del Siegeniense Medio renano en las Cadenas Ibéricas y su paleozoogeografía (Devónico Inferior)]. Revista Española de Paleontología, n⿳ extr. Homenaje al Prof. Gonzalo Vidal, 123-142. ISSN 0213-6937.

Dedicated to Gonzalo Vidal in cordial commemoration of an excursion from Lund to the Iberian Cordillera in June 1971.

\begin{abstract}
At Nigüella (Eastern Iberian Chain), a spatially restricted brachiopod fauna is slightly older than the traditional Middle Siegenian. It is composed of taxa most of which invaded the Rhenohercynicum shortly later, when facies there changed from deltaic to shallow marine. Occurring in typically Rhenish lithofacies, the Niguiella fauna lacks the taxa that are most common in coeval faunas of Ibero-Armorica, but its own taxa have earlier IberoArmorican ancestors and origins, except Multispirifer cf. solitarius and Arbizustrophia n. sp. N. Hitherto, M. solitarius seemed to be an endemic of the Rhenohercynicum; Arbizustrophia was known from the Late Emsian of Asturias; the ancestors of both are unknown in Ibero-Armorica, which suggests viable zoogeographic connections with unknown further regions. Contrary to current opinions, in the late Silurian and early Early Devonian, Ibero-Armorica and Rhenohercynicum do have common taxa, and faunal differences are largely due to facies, especially deltaic facies in the Rhenohercynicum during $7 \mathrm{Ma}$ of late Lochkovian and Pragian time. Effective oceanic faunal barriers lacked. Contradictory plate tectonic scenarios, which had been founded initially on defective faunistic concepts and supposed subduction of various broad oceans, are revised according to faunistic criteria and turn out to be unwarranted also in other aspects. The meanings of the traditional Siegenian substages are elucidated, whereas the actual standard stages cannot be applied to the interval concerned.
\end{abstract}

Key words: Brachiopods, Siegenian, Ibero-Armorica, Rhenohercynicum, palaeozoogeography, palaeogeography.

\section{RESUMEN}

La fauna, espacialmente restringida, de braquiópodos de Nigiiella (Cadena Ibérica Oriental) es ligeramente más antigua que el Siegeniense Medio tradicional. Cuando las condiciones deltaicas cambiaron a marinas someras, la mayoría de taxones que componen esta fauna invadieron, un poco más tarde, el "Rhenohercynicum". Las facies de Nigüella son típicamente renanas, sin embargo, esta fauna no presenta los taxones más comunes en faunas equivalentes de Ibero-Armorica aunque tienen antecesores ibero-armoricanos excepto Multispirifier cf. solitarius y Arbizustrophia n. sp. N. Hasta ahora M. solitarius se consideraba endémico del "Rhenohercynicum" y Arbizustrophica se conocía solamente en el Emsiense final de Asturias; los antecesores de ambos se desconocen en Ibero-Armorica, lo que sugiere conexiones zoogeográficas viables con otras regiones desconocidas. En contra de opiniones actuales, en el Silúrico terminal y en el Devónico temprano, Ibero-Armorica y "Rhenohercynicum" tienen taxones neríticos comunes, y las diferencias en las faunas se deben fundamentalmente a las facies, mayoritariamente deltaicas en el "Rhenohercynicum" durante los 7 Ma de duración del Lochkoviense final y Praguiense. Durante este tiempo no existirían barreras oceánicas efectivas para la fauna. Según criterios faunísticos se revisan diferentes y contradictorios escenarios de tectónica de placas, que inicialmente se basaron 
en conceptos faunísticos erróneos y suponían la subducción de varios océanos anchos. Se aclaran los significados de los subpisos tradicionales del Siegeniense y se demuestra que los Pisos estándar actuales no se pueden aplicar al intervalo estudiado.

\section{Palabras clave: Braquiópodos, Siegeniense, Ibero-Armorica, Rhenohercínico, paleozoogeografía, paleogeografía.}

\section{INTRODUCTION}

Near Nigüella, in the Eastern Iberian Chain, a rather particular Early Devonian brachiopod fauna links IberoArmorica with the Rhenohercynicum. Its age would formerly have been indicated as "Siegenian". Its composition stands out against age-equivalent faunas of Ibero-Armorica, but has much in common with the typical fauna of the traditional, but now obsolete Middle Siegenian substage as coined in Germany and similarly applied also in Belgium. However, a straightforward ageassignment according to the actual standard stages Pragian and Emsian is impossible. And so its plaeozoogeographic interpretation would be under the auspices of the currently leading models of Palaeozoic European plate tectonics. Most such models are initially constructed on palaeozoogeographic fundaments that are often but arbitrarily selected informations on a few fossils whose relevance is exaggerated (e.g. McKerrow, 1994; Franke and Oncken, 1995); however, additional data and hypotheses from other branches of earth sciences are so amalgamated with the initial palaeontologic matters, that it grows very difficult to separate errors from truth. This is the cause to clarify the meanings of some biostratigraphic units in the Early Devonian of South-Western and Central Europe, then to revise some palaeogeographic reconstructions that refer to Ibero-Armorica and the Rhenohercynicum, and finally to reset several aspects of the faunal relations between both regions.

To open the way for an improved palaeozoogeography for the shelly benthos of siliciclastic shelves of Early Devonian Europe requires to eliminate many geologic details that are interwoven with the biostratigraphic matters, in which we are primarily interested as biostratigraphers. Our interference with certain geologic hypotheses of plate tectonics aims at demonstrating the high degree of improbability that is implied in them, because they neglect even basic biostratigraphic data. We try to point out also some evident geologic impossibilities of too daring reconstructions in order to encourage criticism versus misleading palaeogeographic models.

However, there are not only problems with too liberal modern plate tectonics. Formerly, when the fixist concept of structural geology still dominated, the faunal relations between the Rhenohercynicum and Ibero-Armorica were obscured through erroneus age correlations, because the richly fossiliferous Pridolian to Siegenian formations of the Armorican Massif were, one by one, dated about one stage too young. The age assignments in north-western Africa were also linked to those in Armorica, whereas some Gedinnian ages on the Iberian Peninsula were coincident with the Rhenohercynian type regions. Under these conditions, true relations of shallow neritic facies and faunas in the Ibero-Armorican Trough from Celtiberia to eastern Armorica were not realized in due time. In the meantime, structural concepts had been based on radiometry, petrology, metamorphism, tectonic polarity, palaeomagnetism, etc. Being able to apply the same methods both in the crystalline complexes of central Iberia (Galicia) and southern Armorica (Ligeria), structural research proposed a direct connection between both, which cut off nearly all consideration of palaeontologic data in the palaeogeographic reconstructions. It has not been considered why continuous sedimentary troughs and deeper, igneous and metamorphic storeys of structural belts should cross each other, and whether the similarities between Galicia and Ligeria are rather due to the deep storey exposed and to general patterns affecting wider units. The strikingly close similarities expresed by common combinations of partly rather peculiar sediments and faunas in the West Asturian-Leonese Basin and the Middle-North Armorican Domain should be given more credit in palaeogeographic reconstructions. Starting from the fossiliferous neritic sediments of Celtiberia, a resetting of the misleading guide lines for sedimentary and structural belts that are until now so uncritically accepted, should be helpful in ordering the concept of Variscan palaeogeography of Europe.

\section{GEOLOGICAL SETTING AT NIGÜELLA}

The small outcrop area of marine middle Palaeozoic sediments $0.5 \mathrm{~km} \mathrm{~W}$ of the village Niguiella (Province of Zaragoza; Mapa Geológico de España 1:50.000, Hoja n ${ }^{\circ}$ 381: Illueca; Fig. 1) belongs to the Nigüella Axial Depression of the Herrera Unit in the Palaeozoic basement of the Eastern Iberian Chain. It displays late Silurian to Early Emsian strata. Valenzuela Ríos (1984, 1989) grouped them in the same formations as their age equivalents in the Río Cámaras Axial Depression situated some $60 \mathrm{~km}$ along strike to the SE (=Nogueras area). The beds, the fauna of which is studied here, occupy a lithostratigraphic position amid the upper half of the Santa Cruz Formation.

The Santa Cruz Formation has its studied outcrop north above the driveable field way of Barranco de los Hoyos towards Collado de Piedra, above the sheep folds Corrales del Otro Lado and Paridera Alta, in the southern slope of the mountain Alto de la Cruz. The strata are moderately folded and fractured, but they have received a 
notable schistosity and distortion that also penetrates the sandstones and deforms the fossils; the moderate dips are mainly towards NW. The Devonian strata have been overthrust by Early Cambrian Ribota Dolomite that tops the mountain.

We compare the Santa Cruz Formation of Niguiella with the Santa Cruz Formation in the Nogueras area, although the development of the unit differs in many details between both areas: its thickness at Niguiella is only one third of that near Nogueras; neither are the characteristic rhythmothems (Carls, 1988) distinctly developed at Nigüella, nor are most of the faunal horizons represented. Nevertheless, the correlation of the Nigüella fauna is not problematic. The top of the underlying Nogueras Formation is mappably identified and its age early within the original Pragian is warranted. The base of the overlying Mariposas Formation is marked by a first limestone bed that furnishes Icriodus sigmoidalis Carls and Gandl, 1969 (Valenzuela Ríos, 1984, 1989) and Polygnathus excavatus: in analogy with the Nogueras area, this upper level is close to the beginning of the classic Emsian; it is within the $P$. excavatus Zone and is much younger than the redefined $P$. kitabicus boundary of the Emsian.

Within this frame of base and top, at Nigüella, the Santa Cruz Formation measures 96 m. It is made up as follows (from base to top):

I) A basal unit of predominantly fine shales with few marly and arenaceous intercalations may be some $43 \mathrm{~m}$ thick. It corresponds largely to member d3a of the Santa Cruz Formation near Nogueras, but its upper parts may overlap with low levels of member $d 3 b$ of the same formation.

II) Within the next $21 \mathrm{~m}$ (lower part of local unit Ni1/7), increasingly, but still scarce, sandstone beds are intercalated in the shales. One sandstone bed near the base measures 30 to $40 \mathrm{~cm}$ and contains Acrospirifer sp. (The genus Acrospirifer begins, in the Nogueras area, in the unit d3a-beta-I of the Santa Cruz Formation; its succession of species reaches the lower parts of the Mariposas Formation.)

III) The following about $20 \mathrm{~m}$ are an alternation that grows richer in quartzitic beds and is more fossiliferous than the preceding strata; the brachiopods of the Niguiella fauna treated herein (Fig. 4) are found from float and from a few outcropping fossiliferous nests amid this interval, about $20 \mathrm{~m}$ below the top of the Santa Cruz Formation. The sandstone beds are partly cross-bedded and rippled and are a few $\mathrm{cm}$ up to $60 \mathrm{~cm}$ thick. Accumulations of fine shell detritus furnish conodonts, mainly fragmented Icriodus (see below).

IV) Towards the top of the Santa Cruz Formation, in about $12 \mathrm{~m}$ of predominant silty shales, sand intercalations decrease. Only the uppermost $4 \mathrm{~m}$ of this interval with partly intense bioturbation remind of the Member d $3 \mathrm{c}$ of the Santa Cruz Formation of the Nogueras area, which is up to $106 \mathrm{~m}$ thick and is also bioturbated, but almost barren of shelly fauna.

The dominating fossils of the Nigüella fauna are disjunct big shells of brachiopods; lamellibranchiates are

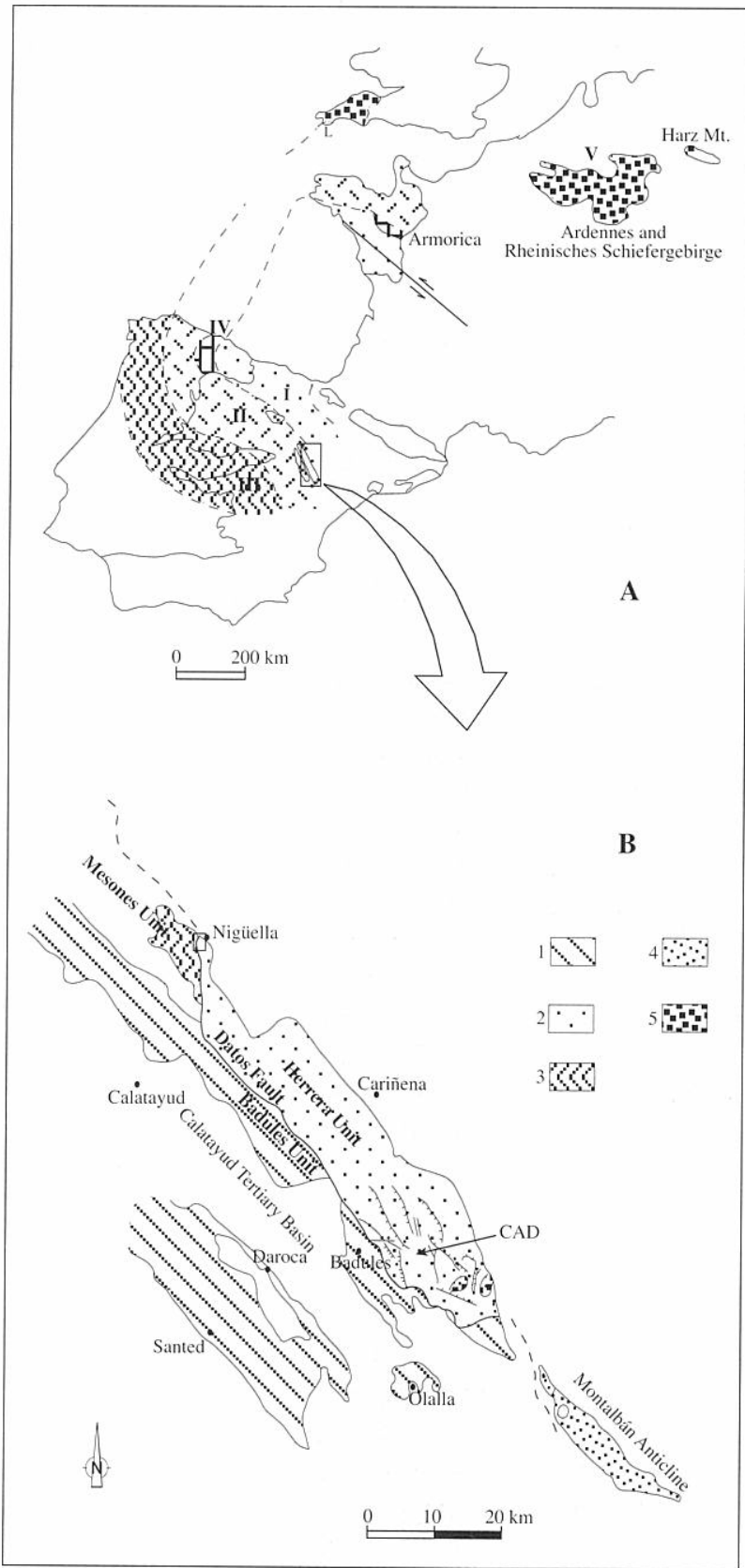

Figure 1. A. Palaeogeography of south-western and centralnorthern Europe during the Lower Devonian (modified from Carls, 1988). I=CantabrianEbroian Massif and crystalline zone of southern Armorica. II=Ibero-Armorican Trough plus margin of probable continuation in southern Iberia and in Rhenohercynicum. III=Central Iberian Zone $s . s$. (=Galician-Castilian Zone). IV=Important carbonate facies along margins of stable subsurface structures. V=Rhenohercynian Zone. $\mathrm{L}=$ Lizard Complex. - B. Structural sketch of the Eastern Iberian Chain (modified from Carls, 1983). $1=$ Badules Unit (Precambrian-Ordovician). 2=Herrera Unit (Upper Cambrian to Devonian). 3=Mesones Unit (Lower to Middle Cambrian). $4=$ Herrera Unit (Namurian and Westfalian). $5=$ Thermal aureole. CAD $=$ Cámaras Axial Depression. 


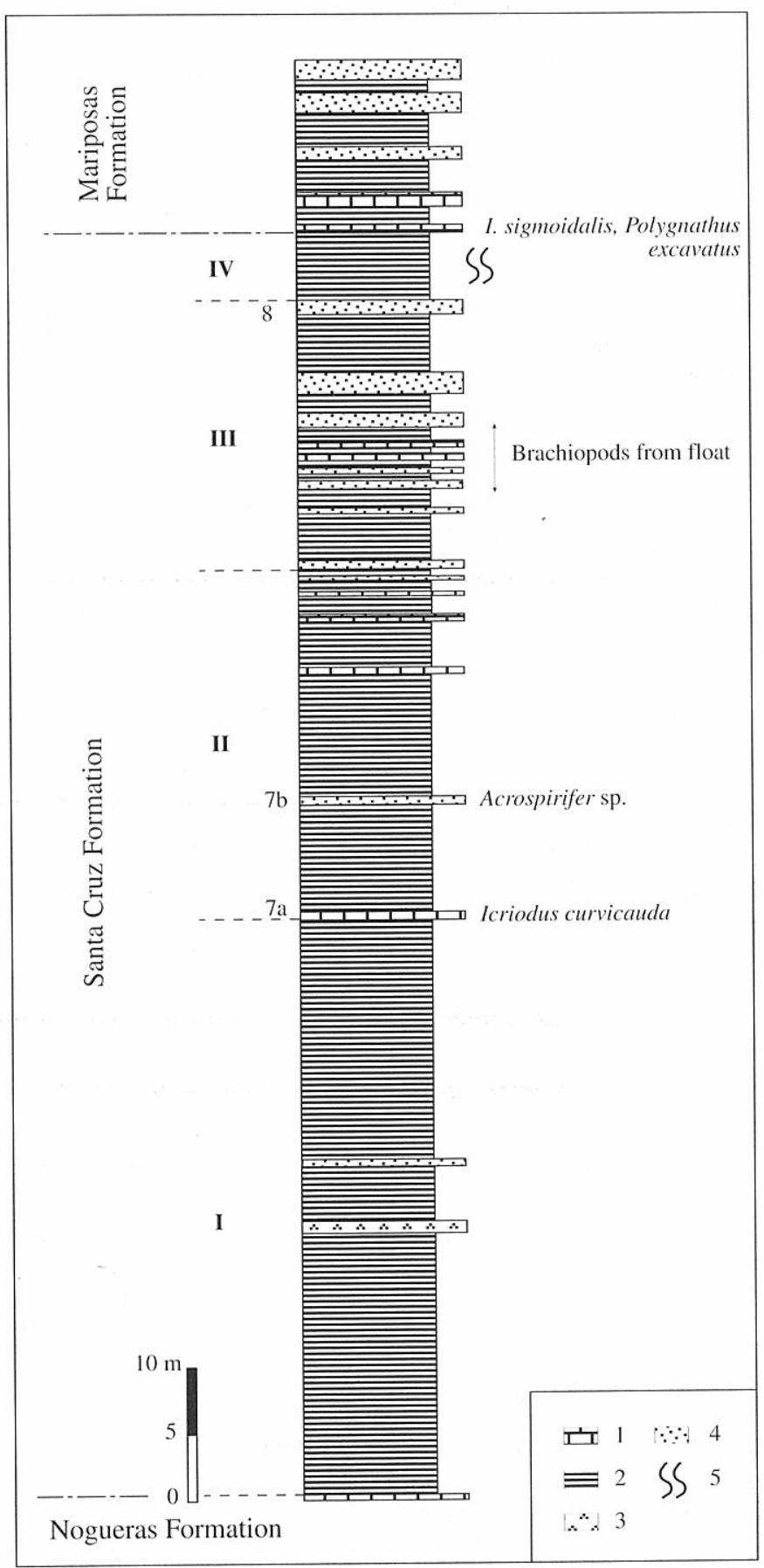

Figure 2. Stratigraphic column Ni 1. I-IV=lithologic subdivisions described in text. $7 \mathrm{a}, 7 \mathrm{~b}, 8=\mathrm{bed}$ numbers painted in the field. Legend: $1=$ limestone; $2=$ shale; $3=$ marl 4 =sandstone; $5=$ bioturbation.

subordinate. Sedimentary transport has abraded many specimens, but others have well preserved Steinkerne. Variscan deformation has distorted the fossils to some degree which, however, still allows specific identifications. Natural weathering does not remove the partly dolomitized shell matter sufficiently; therefore, the fossiliferous rocks recovered from outcrops must be leached with hydrochloric acid in order to obtain Steinkerne and moulds.
Due to the fact that most important finds stem from float, we have not subdivided the fauna bed by bed. Although only about $10 \mathrm{~m}$ of thickness furnish fauna (Fig. 2), there might be age-relevant changes from bed to bed, but we have not obtained hints at such. It rather seems that the fossiliferous interval corresponds to only one sequential pulse that comprises short time without relevant biostratigraphic change.

Through some of its brachiopods, mainly Acrospirifer aff. primaevus (Steininger, 1853) (Pl. I, figs. 1-3), the present fauna is correlated biostratigraphically with a narrow interval high within the submember d3b-gamma of the Santa Cruz Formation near Nogueras (see discussion below). This coincides well with its position within the section. The conodonts Icriodus curvicauda Carls and Gandl, 1969 (frequent) and Icriodus angustoides angustoides Carls and Gandl, 1969 (scarce final occurrence) (Fig. 2) support this correlation, as this exceptional association (after a long absence of Icriodus angustoides) is also known from the middle of submember d3b-gamma (Carls, 1975). Icriodus angustoides also reappears in equivalents at the Rade de Brest (western France; Morzadec et al., 1988: 23), scarcely $20 \mathrm{~m}$ below the top of the Formation du Faou, hardly $15 \mathrm{~m}$ below the classic beginning of the Emsian. (We correlate the classic Emsian boundary in the middle of the "Bancs des monstres", that is at a higher level than former authors in Armorica.) Due to these correlations, it is possible to evaluate the Niguiella fauna in spite of its contrasts with its age equivalents in the Nogueras area and at the Rade de Brest. The Nigüella fauna, although also consisting of big-sized brachiopods, must not be confounded with the Armorican faunas of the "Bancs des monstres" near the top of the Formation du Faou, which is younger and has a more Ibero-Armorican composition.

\section{COMPOSITION OF THE NIGÜELLA FAUNA}

The Nigüella fauna has not yet been exploited thoroughly, but what has been identified hitherto, is sufficient to state that it can be compared most intimately to the fauna of the Mittlere Siegen Schichten of the Siegerland, although its age must be slightly older. Most remarkable, however, is not the age, but the generic and specific composition of the fauna: a comparable grouping is elsewise only found in the Mittlere Siegen-Schichten of the Rhenohercynicum.

The fauna comprises the following taxa of primary biostratigraphic interest:

Multispirifer cf. solitarius (Krantz, 1857)

Acrospirifer aff. primaevus (Steininger, 1853)

Rhenorensselaeria strigiceps (Roemer, 1844)

Further brachiopods of the Nigüella fauna are:

Platyorthis circularis (Sowerby, 1842)

Schizophoria sp.

Boucotstrophia herculea (Drevermann, 1904)

Arbizustrophia n. sp. N 
? Athyrididae indet.

Mauispirifer gosseleti (Beclard, 1887)

? Tenuicostella $\mathrm{sp}$.

Meganteris cf. archiaci (Verneuil, 1850)

Additionally, the fauna comprises:

Pleurodictyum sp. with wide mural pores

"Favosites" sp. (a big globular stock)

"Tentaculites" sp.

Bucanella sp.

Lamellibranchiata

Crinoid remains (1 high anal tube)

Trilobite remains (scarce homalonotid thoracic segments)

Ropalonaria sp. and other borings in shells

Of the brachiopods, only Arbizustrophia sp. does not occur in the Rhenohercynicum. In Spain, this genus was known with its type species Arbizustrophia diaphragmata García-Alcalde, 1972, a small-sized taxon (up to $14 \mathrm{~mm}$ long) within the Late Emsian of Asturias. The present species is up to $25 \mathrm{~mm}$ long and $33 \mathrm{~mm}$ broad. Like Multispirifer, it has its first known occurrence here without a hint as to its origin.

\section{THE CLASSIC SIEGENIAN STAGE AND THE BIOSTRATIGRAPHIC SIGNIFICANCE OF THE MIDDLE SIEGENIAN}

Before the significance of the above fauna is discussed, it is necessary to consider the stratigraphic significance of the classic Siegenian and its substages, especially the Middle Siegenian. Although these units are formally obsolete and have been excluded from the global standard stages, most of the biostratigraphic informations concerning the middle parts of the Early Devonian have been documented in terms of these classic units, however problematic they were. Carls et al. (1982) have outlined the essentials of the Siegenian Stage with reference to its type area; however, the long duration of the Early Siegenian and the short duration of Middle plus Late Siegenian were not yet realized. Godefroid and Stainier (1982) have provided revised information concerning important sections in Belgium.

The classic stages (and substages or "Gruppen") of the Rhenish Biofacies of the Early Devonian have been coined in the Rheno-Ardennan Slate Mountains of the Rhenohercynicum. They have not been applied uniformly even within their type regions. Here we refer mainly to the Siegenian. Its type region is the Siegerland, east of the Rhine near Siegen. The Siegenian Stage was conceived so as to coincide with the sum of Untere, Mittlere plus Obere Siegen-Schichten, each of which typified the corresponding substage. In correlations between different parts of the Rhenohercynicum (Belgium, Germany), the boundaries of the stage and of its substages were not stable, because thick sediments of deltaic facies without marine shelly faunas were correlated under partly diverging concepts and because the Emsian Ulmen"Gruppe" was added transiently to the Siegenian.
Changing applications of the Rheno-Ardennan and Bohemian stage names have made it necessary to state explicitly the sense in which a stage name is used. Therefore, we refer to the Siegenian/Emsian boundary as to the classic one, if it is understood as in the Rhineland (Herdorf/Ulmen; Acrospirifer primaevus/fallax). By "original Pragian" we understand the span that ends at the beginning of the Zlichovian.

The beginning of the Siegenian had to be sought in deltaic sediments. Carls (1987), in an attempt to preserve the Siegenian Stage as a global standard, demonstrated that the beginning of the stage was quite close to the beginning of the Pragian. The strata of the Untere Siegen-Schichten (Tonschiefer-"Gruppe") measure up to about $1 \mathrm{~km}$ in thickness. In a calibration just going to press, Carls (unpublished data) shows that the fossiliferous age equivalents of the Untere SiegenSchichten in Ibero-Armorica represent a time span of over $5 \mathrm{Ma}$. Together with the Late Gedinnian of the Rhenohercynicum, which is also represented by deltaic facies and lasted nearly $2 \mathrm{Ma}$, this long interval withheld marine biostratigraphic information from the main parts of the Rhenohercynicum. Therefore, a long and rich succession of shelly faunas in Mauro-Ibero-Armorica could formerly not be referred to the classic standard. Many attempts to assign marine shelly faunas to the Gedinnian or to the Siegenian according to the Rhenohercynian standards could only aim at the Early Gedinnian or at the Middle Siegenian marine faunas. That the duration of the barren interval was so long, has not been realized. Now that the scope of the Early Siegenian can be outlined in Ibero-Armorica, this time span may be qualified as the most finely horizonted interval of the Early Devonian, due to Ibero-Armorican faunas. However, that cannot be applied to the type region of the Siegenian itself. Probably, the redefined beginning of the Emsian (Polygnathus kitabicus boundary) is somewhere in the later half of the classic Early Siegenian (Carls and Valenzuela-Ríos, 1997), which provides new sources of confusion.

The classic Middle Siegenian began with the appearance of a characteristic marine shelly fauna in the Rhenohercynicum. It distinguishes the Mittlere SiegenSchichten (Rauhflaser-"Gruppe") from the underlying deltaic deposits. Drevermann (1904) has given an exemplary description of the fauna of Seifen with most of the relevant taxa. Dahmer (1934) completed the knowledge through several successive horizons, and Paproth (1960) tabulated further collections through the entire Mittlere Siegen-Schichten of the type region Siegerland. Remarkably, the successive faunas in up to $700 \mathrm{~m}$ of sediment in the Siegerland do not reveal essential phylogenetic progress, and their differences from each other are mainly ecologic ones. It is likewise remarkable that a number of brachiopod taxa with elaborate morphology - like Plicostropheodonta murchisoni (Archiac and Verneuil, 1842), Vandercammenina bischofi (Giebel, 1858), and Euryspirifer dunensis (Kayser, 1889)_ still range through much of the classic Early Emsian. 
The brachiopod species of the Mid-Siegenian type fauna did not originate in the Rhenohercynicum, but they invaded this region as fully developed species, when it was flooded by the marine waters of a shallow shelf. Therefore, their true biostratigraphic ranges have begun essentially before their entries in the Rhenish sections facts which cannot be recognized and controlled within the Rhenohercynicum itself. Outside the Rhenohercynicum, the beginning of the classic Middle Siegenian cannot be reproduced exactly by means of the origin of a defined index taxon, as no such index origin has been used in the definition of the substage. Therefore, the intra-specific evolutionary progresses of relevant brachiopod stocks must be analysed in order to identify the state that they reached at the beginning of the Middle Siegenian in its type region. E.g., in the Nogueras area, there is a succession of early taxa of Euryspirifer, wherein the state of evolution of Euryspirifer dunensis of the Mittlere Siegen-Schichten was not yet reached in the basal beds of submember d3b-gamma of the Santa Cruz Formation, which demonstrates that the Middle Siegenian is younger than that level.

The brachiopod species referred to in the above lists from Nigüella comprise some of the biostratigraphically most important taxa of the Mittlere Siegen-Schichten, but neither are the lists already complete nor may all relevant Mid-Siegenian taxa be expected to be present at Nigüella. Up to now, older (Early Siegenian) occurrences of brachiopod species that were considered as MidSiegenian guides, were not recognized as being so old, because they were dated as Mid-Siegenian or even younger, but now it can be confirmed that appearances exist in Ibero-Armorica that are older than the Mittlere Siegen-Schichten, and that applies also to the Niguiella fauna.

Here are a few special characters of the faunas of the Mittlere Siegen-Schichten in the Rhineland: the diversities are high. Multispirifer solitarius s. s. is known only from the Mittlere Siegen-Schichten, whereas Acrospirifer primaevus and Rhenorensselaeria strigiceps persist in the Obere Siegen-Schichten. In the Rhenohercynicum, Rh. strigiceps is known from the beginning of the Mittlere Siegen-Schichten and has been proposed as the index of the Early Siegenian/Middle Siegenian boundary (Mittmeyer, 1982); generally, it is very scarce within the Mittlere Siegen-Schichten and becomes frequent only in the Obere Siegen-Schichten. Remarkably, also Chonetes and other Chonetacea are absent from the typical Mid-Siegenian faunas, whereas Chonetes abounds in the Obere Siegen-Schichten and was also present in Ibero-Armorica before, during and after Mid-Siegenian time, but lacks at Niguiella. These features depend on ecology and biofacies rather than on age: the Seifen type of faunas must imply some factor that is prohibitive for Chonetacea.

Carls $(1987: 81,101)$, in an attempt to balance the substages of the Siegenian, proposed to begin the Middle Siegenian at the entry of Acrospirifer beaujeani (Beclard, 1895) in unit d3a-beta-I of the Santa Cruz Formation (step Spir.12) near Nogueras. This proposal is obsolete, as the Siegenian Stage was cancelled as a standard. In the present correlations, we do not refer to that proposal.

The classic Late Siegenian (Herdorf-"Gruppe") was distinguished from the Middle Siegenian partly through the lack of Multispirifer solitarius, through transitorily decreasing participation or lack in the brachiopod faunas of Euryspirifer, Vandercammenina, and of large Stropheodontidae, which had their come back in the Early Emsian. Positively it was characterized by the true range of Hysterolites hystericus hystericus Schlotheim $s$. $s$. The frequent presence of Rhenorensselaeria, Tropidoleptus and Chonetes is rather ecology-controlled. Remarkably, Acrospirifer primaevus still ranges through the Late Siegenian; its end is used as a practically important mark at the classic Siegenian-Emsian boundary in the Rhineland.

For some time, the Ulmen-"Gruppe", originally the oldest subdivision of the classic Early Emsian, had been added to the Siegenian (Solle, 1953), but this has been undone later. Fuchs (1982: 252, text-fig. 10) and mainly Mittmeyer (1974: 72; 1982: 262) redefined the beginning of the classic Emsian, as understood in the Rhineland, at the level where Acrospirifer primaevus is released by $A$. fallax (Giebel, 1858).

A translation of the above data into the actual global standard stages is not possible, because the position of the Polygnathus kitabicus boundary of the Emsian in terms of the classic scale and in relation to the sections of the original Pragian in Bohemia is unknown. The classic beginning of the Emsian is within the Polygnathus excavatus Zone.

\section{ABSOLUTE TIME DURATIONS INVOLVED}

Critical inspection of the radiometric data and the results thereof obtained by Harland et al. (1990) and similar evaluations reveals that those results are useless for a quantitative analysis of the time, within which the events discussed here took place. Setting the interval from the beginning of the Lochkovian to the beginning of the Late Emsian (Dalejian) as $14 \mathrm{Ma}$, Carls (unpublished data) has just worked out a calibration within this span parts of which are already available (Carls in Weddige, 1996: 274-278; incorporating also ranges from outside Celtiberia). This calibration subdivides the time in proportion to relevant evolutionary steps in half a dozen of groups of good guide fossils. In this context, the entire span is subdivided into 23 spiriferid steps, 22 conodont steps, 20 trilobite steps, etc. Correlating the Nigüella fauna, we are concerned especially with spiriferid step Spir.17; reference is also made to step Spir.16 with Arduspirifer rolfwerneri nom. nud. and Acrospirifer jessjohnsoni nom. nud. as the preceding interval, and to the following step Spir.18 that corresponds to the entire classic Middle Siegenian. Combining the six groups of fossils, a duration of 1.2 Ma for the sum of steps Spir.16-18 would result. The main part of the Late Siegenian (Herdorf) 


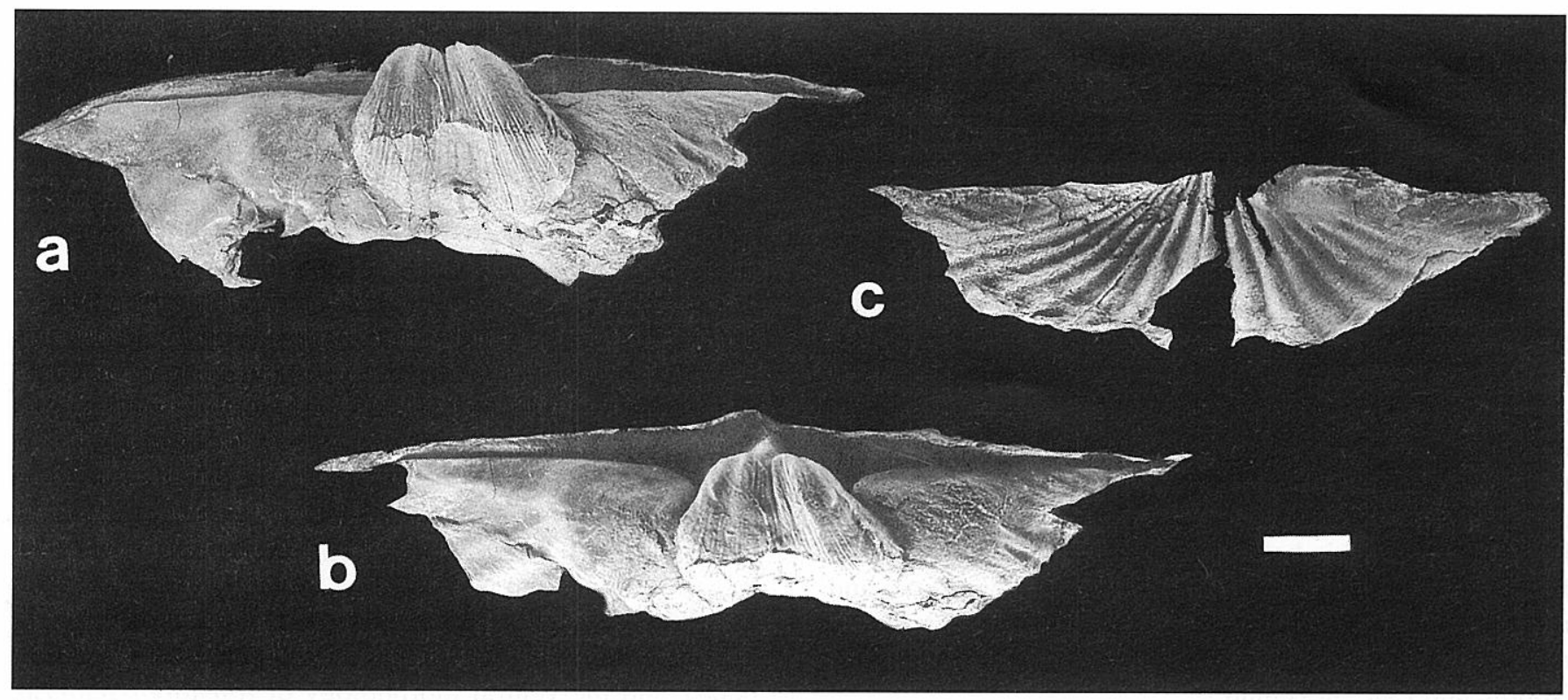

Figure 3. Acrospirifer aff. primaevus (Steininger, 1853) from section Valdelacasa, $0.84 \mathrm{~km} \mathrm{~N}$ of church of Nogueras; 0.177 $\mathrm{km} \mathrm{W}$ of road Nogueras-Villar de los Navarros; $25 \mathrm{~m} \mathrm{~N}$ of creek north of irrigation ditch. Mapa Geológico de España 1: 50.000, Sheet 466: Moyuela; x: 819.750; y: 729.950; Submember d3b gamma, $10.2 \mathrm{~m}$ below top; $2.6 \mathrm{~m}$ above base of set 23. Specimen MPZ 98/463. Scale bar=1 cm. • a. Steinkern of pedicle valve, ventral view. Nearly entire width is preserved; length incomplete. Note longitudinal striation of diductor fields. No gonoglyphe. $\bullet$ b. The same, postero-ventral view. Note additional radiating striation in posterior parts of diductor fields. Remnants of tooth plates. $\bullet$ c. The same, outer mould. Note the single intrasinal costa. Growhtlines outline mucronations.

only corresponds to step Spir.19. However poor the exactness of this evaluation of evolutionary progress for the calibration of time may be, it certainly demonstrates the brevity of the time related to the Middle Siegenian and the faunas near its beginning. This aspect can be additionally confirmed as follows:

Acrospirifer primaevus is a taxon with a very elaborate morphology that can be recognized with certainty in spite of its high variability of the ventral interior. Historically, it has been taken for the distinguishing index of the entire Siegenian, but in the Rhenohercynicum, it is limited to the Mittlere SiegenSchichten and Obere Siegen-Schichten. According to all experience, most turbidicolous spiriferacean species with such elaborate features of functional morphology turn out to have a short range, if they are duely revised. The fact that up to $4,000 \mathrm{~m}$ of clastics in the Mittlere SiegenSchichten plus Obere Siegen-Schichten were accumulated (only in the Rhenohercynicum) in less time than the true range of this taxon, might cause the impression that it had quite a long range. However, within the observed range in the Rhenohercynicum, there are hardly relevant phylogenetic changes in other lineages of brachiopods or trilobites that would suggest the progress of time. Abstracting from palaeoecologic variations in the diverse faunas, which have been arranged in a chronologic succession through regional mapping, there is, indeed, very little biostratigraphic progress from Middle to Late Siegenian. Thus, it would be quite difficult to decide, whether a single though rich fauna in a distant region with most Middle to Upper Siegenian guide brachiopods should be attributed to the
Middle or to the Late Siegenian. Furthermore, the sediment thicknesses that correspond to revised Acrospirifer primaevus in Celtiberia and Armorica, according to correlations based on other taxa, are hardly $20 \mathrm{~m}$ at Nigüella and at the Rade de Brest; approximately $110 \mathrm{~m}$ in the Nogueras area of Celtiberia are comparatively much and are combined to locally increased input of detritus.

\section{THE AGE OF THE NIGÜELLA FAUNA}

Because of the early evolutionary stage of Acrospirifer aff. primaevus, we correlate the entire fauna at a level just anterior to the origin of $A$. primaevus. Most other taxa of the fauna would allow a longer range. A. aff. primaevus may be considered as the ancestor of $A$. primaevus s. $s$. Although the phylogenetic step from $A$. aff. primaevus to $A$. primaevus $s$. $s$. is not stratally documented, it is conclusive that it took place before the fauna of the Mittlere Siegen-Schichten appeared in the Rhenohercynicum. Consequently, we date the Nigüella fauna as rather late Early Siegenian in the classic sense. If someone would install a spiriferid successive appearance zonation with an Acrospirifer primaevus Zone (we do not recommend such unnecessary formalism), then the Niguiella fauna would be just before the beginning of that zone.

Acrospirifer aff. primaevus (Fig. 3) occurs also in bed $23,10 \mathrm{~m}$ below the top of submember d3b-gamma in the section Valdelacasa in the Nogueras area, and it has been figured as "Acrospirifer primaevus (Steininger)" by 
Gourvennec (1989: 61, pl. 3, figs. 1-13). Among Gourvennec's figures, we refer especially to the specimen of figure 8 from the overlap of Adolfia watersi Gourvennec, 1989 and Mauispirifer gosseleti (Beclard, 1887) in the section Montguyon in the eastern Armorican Massif. (Adolfia watersi enters near Nogueras in the basal part of submember d3b-gamma of the Santa Cruz Formation.) From their positions high above the beginning of the Pragian and of the classic Early Siegenian in their respective sections, it also results that these occurrences of Acrospirifer aff. primaevus concern a very young level of the Early Siegenian. In recent articles on the biostratigraphy of Armorica, approximately this level has been considered as the vicinity of the classic Siegenian/Emsian and Pragian/classic Emsian boundaries, but this has to be revised; Carls (1987: textfig. 3) has already given some hints to this correction, and additional arguments are produced herein: especially the early state of the lineage with the main index of classic Middle and Late Siegenian.

Multispirifer cf. solitarius (Pl. I, figs. 4,5) is identified with reserve because the fascicostate ribbing of the available material differs from our well preserved material of $M$. solitarius s. $s$. in the Siegerland. Three effects seem to be combined here: The crests of the primary costae are rounded, which is probably due to abrasion during transport; additionally, the fascicostate relief has been slightly blurred through tectonic deformation; thirdly it is possible that the fascicostate ribbing was not yet so strongly developed as in $M$. solitarius $s$. s., in which case we would be concerned with an ancestral taxon. Especially the latter case would corroborate the final Early Siegenian age assignment based on Acrospirifer aff. primaevus. Up to now, $M$. solitarius was known only from the classic Middle Siegenian of the Rhenohercynicum.

The presence of Rhenorensselaeria strigiceps (Pl. I, figs. 8-11) in the Nigüella fauna would allow its inclusion in both the classic Middle and Late Siegenian, but a slightly older age cannot be excluded through the observations in the Rhenohercynicum, where the deltaic facies may have delayed its entry. Carls (1987: 84) reported "Rhenorensselaeria sp. e. g. strigiceps" from the Santa Cruz Formation from submember d3b-alpha up to submember d3b-delta (this upper end of the range needs revision). However, García-Alcalde (1992: 58) rightfully drew attention to the presence not of Rhenorensselaeria, but of Globithyris in the middle of the Santa Cruz Formation. His descriptive remarks apply to material from the arenaceous submember d3b-alpha and from shales with the "Lavadero" fauna high in unit d3b-beta-2. Upward, the gradual approach toward Rhenorensselaeria can be observed in the middle of the alternation of sandstones and shales d3b-beta- 3 in the Nogueras area.

Our distinction between Globithyris and Rhenorensselaeria now follows García-Alcalde's (1992) remarks, but still encounters difficulties that are partly due to ontogenetic changes. The outlines of undoubted Globithyris in shales near the top of unit d3b-beta-2 are rather circular and reach widths near $60 \mathrm{~mm}$ with up to 80 costae, but they are only about half so thick as wide. Its tooth plates are long and thin and so is the dorsal median septum, whereas a ventral median ridge is absent or hardly indicated. Rhenorensselaeria strigiceps from the Late Siegenian of the Rhenohercynicum and from Nigüella grows, toward maturity, rather globular and even elongate; thereby, the ventral muscle area is rotated into a posterior direction and is oriented at a stronger angle relative to the commissure. The tooth plates shorten and diverge dorsally; the ventral median ridge becomes a stout ridge of triangular section or even a septum in a steep posterior position; the dorsal median septum likewise appears to be shortened in dorsal view, due to this rotation. In a population from sandstone layers of package 9 in the middle (25.4 m below the top) of unit d3b-beta-3 of the Santa Cruz Formation in section Valdelacasa $(0.8 \mathrm{~km} \mathrm{~N}$ of Nogueras) there are both ventral interiors like those of Globithyris of unit d3bbeta- 2 and the ventral morphology of Rhenorensselaeria resembling the specimen figured here from Niguiella (Pl. I, fig. 8). In the same bed, some of the dorsal interiors have at the beak, beside the small perforation of the cardinal plate, a pair of small grooves with about a dozen of longitudinal lamellae that serve as diductor attachments (reminding of "cardinal processes" of Spiriferacea), whereas other specimens do not have this feature. In this bed, the Globithyris morphology and the Rhenorensselaeria morphology coexist. The taxonomic problem how to separate both forms must still be solved, but biostratigraphically we may count here with the origin of Rhenorensselaeria strigiceps.

Remarkably, the shell sizes in the GlobithyrisRhenorensselaeria lineage diminish from a probable maximum in submember $\mathrm{d} 3 \mathrm{~b}$-alpha toward the small Rhenorensselaeria demerathia Simpson, 1940 in the final Late Siegenian Saxler Formation and its equivalents (Hüllbuche fauna) in the Rhine region and in the Emsian. Dahmer (1934: 74-75) discusses whether "Rhenorensselaeria" propinqua (Fuchs, 1904) might be a juvenile morph of Rh. strigiceps, but discards this possibility; under this name, small forms are reported from Middle and Late Siegenian strata of the Rhineland that resemble the Globithyris of unit d3b-beta-2, but are much smaller. "Rhenorensselaeria" crassicosta (Koch, 1881) seems not to belong to the lineage discussed here.

The latter observations underline the vicinity of the classic Early Siegenian/Middle Siegenian boundary, because in the type Middle Siegenian true Rhenorensselaeria strigiceps was already fully developed. The formerly assumed phylogenetic derivation of Globithyris from Rhenorensselaeria does not apply, because the evolutionary way had the opposite direction. (Consequently, correlations between the Appalachian Realm and the Rhenish faunal succession that were based on these genera, must be revised.) As the findings from Niguiella are fully developed $R h$. strigiceps, they confirm that the Nigüella fauna is younger than the middle of unit d3b-beta-3 in the Nogueras area with the transitional morph. 


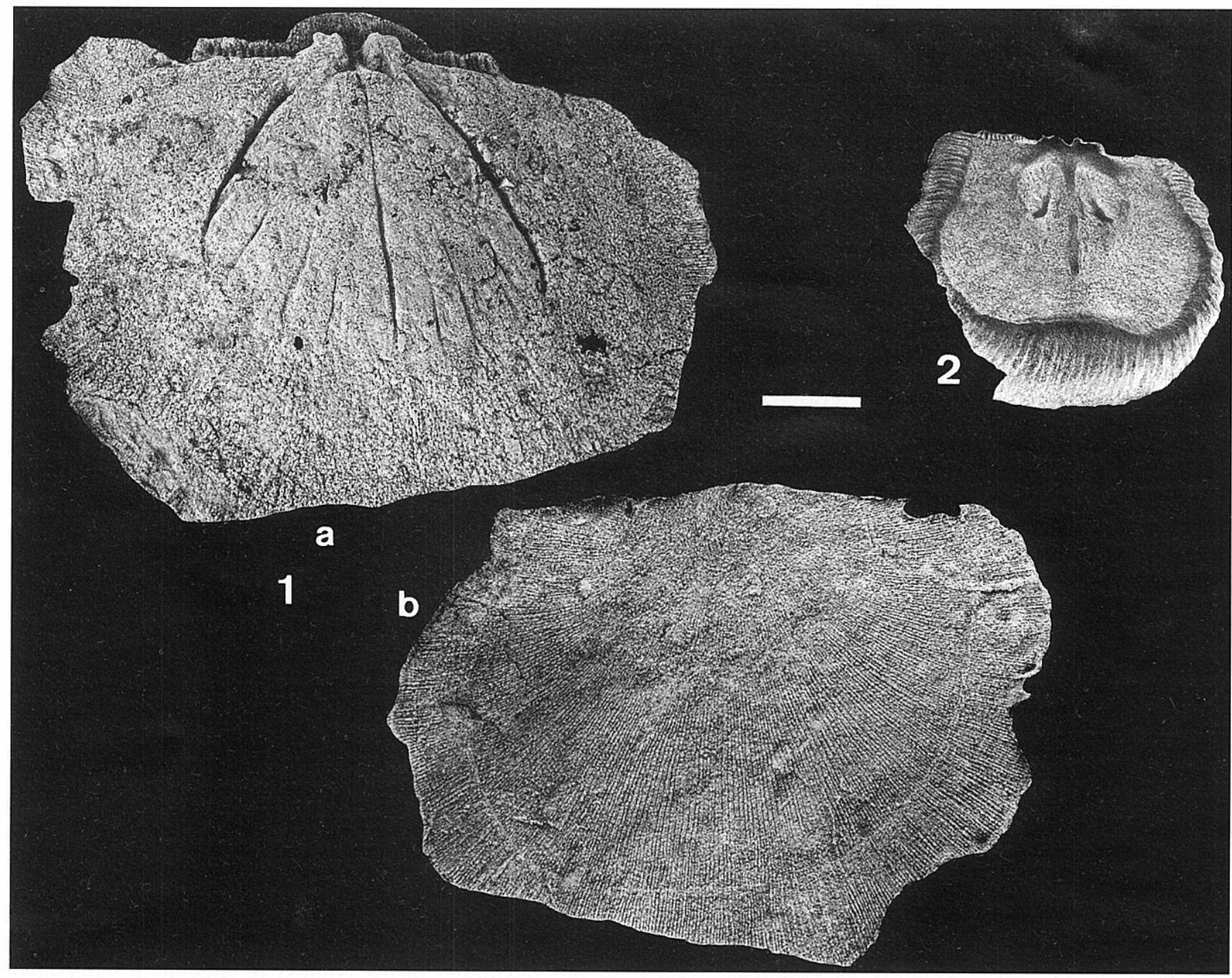

Figure 4. Brachiopods from Nigüella; southern slope of Alto de la Cruz, float about $20 \mathrm{~m}$ below top of Santa Cruz Formation. Scale bar=1 cm. • 1. Boucotstrophia herculea (Drevermann, 1904). Pedicle valve (MPZ 98/475). • a. Steinkern. • b. Outer mould. Note degree of tectonic deformation in growth line. • 2. Arbizustrophia n. sp. N. Steinkern of brachial valve (MPZ 98/476). Note high diaphragm and interrupted median septum.

The other taxa of the Nigüella fauna exist also in the Mittlere Siegen-Schichten of the Rhenohercynicum; most of the species (but for Mauispirifer gosseleti) reach the classic Emsian. As to their origins, some can be traced back into the time of the Early Siegenian elsewhere in Ibero-Armorica. Pre-Middle Siegenian origins could not be realized in the Rhenohercynicum, due to the absence of marine shelly faunas there. A continuous lineage of intra-specific development produces Platyorthis circularis already amid the classic Early Siegenian of Ibero-Armorica. Leptostrophiella explanata enters in the Nogueras area at the base of submember d3b-gamma (or earlier?; it was not found with certainty at Nigüella, but is present in the Middle Siegenian type fauna). Mauispirifer gosseleti was found by Gourvennec (1989) in the Armorican Massif already at levels that correspond to submember d3b-beta.

Resuming, the Nigüella fauna has an age of final Early Siegenian in the classic Rhenish sense. It comprises mainly such taxa that belong to the typical fauna of the Mittlere Siegen-Schichten in the Siegerland or that are immediate ancestors of such. This association differs from other Ibero-Armorican faunas of comparable age, which have Corylispirifer, Adolfia watersi Gourvennec, 1989, Plicanoplia, Plebejochonetes buchoti (Renaud, 1942), Ctenochonetes aremoricensis (Racheboeuf, 1976) and Loreleiella dilatata (Roemer, 1844) in wide regional distribution. These latter taxa are absent from the Nigüella fauna which, thus, is of rather unsual composition within Ibero-Armorica. Nevertheless, it would not be correct to consider it as exotic, because most of its components also occur elsewhere in IberoArmorica and/or have older relatives (and some have younger ones, which is, however less relevant in this context). It is merely a special, ecologically induced selection of Ibero-Armorican taxa — but for Multispirifer and Arbizustrophia, which are unknown elsewhere in Ibero-Armorica at or before this level. 


\section{GENERAL ASPECTS OF THE PALAEOZOOGRAPHIC SIGNIFICANCE OF THE NIGÜELLA FAUNA}

At first sight, the Nigüella fauna establishes closer faunal relations between the Rhenohercynicum and IberoArmorica in the early Devonian than other faunas do. It is by far not the only good faunal link, but it is the most remarkable and even striking one. However, at a closer look and after due interpretation, the first impression undergoes some modifications. Some questions to be solved are these: Where did the Nigüella fauna come from? Was it the source or a derivative of the fauna of the Mittlere Siegen-Schichten? What were the possibilities of faunistic interchange between Nigüella and the Rhenohercynicum? Are current palaeogeographic models and the observed distribution of faunas compatible?

Differences between Early Devonian Faunas in IberoArmorica and in the Rhenohercynicum exist, but they are not absolute, and both the differences and the close similarity between the Nigüella fauna and the faunas of the Mittlere Siegen-Schichten are rather a matter of degree. From early Lochkovian to early Eifelian time, many taxa of brachiopods and trilobites are common to both regions, but usually they occur together with more associates that are not shared by both regions and that constitute differences between Ibero-Armorican and Rhenohercynian faunas, which are often more conspicuous than the shared elements.

Beyond that, a good deal of seeming faunal differences between the Rhenohercynicum and IberoArmorica is palaeozoogeographically meaningless, because it is simply due to the absence of fully marine biofacies in the Rhenohercynicum during about $7 \mathrm{Ma}$, from the late Lochkovian through most of what formerly was the Early Siegenian. Many Ibero-Armorican marine taxa delimited to this interval simply could not live in the deltaic facies of the Rhenohercynicum, even if their larvae reached its vicinity. In reality, whenever the facies allowed for it (early in the Lochkovian, from Middle Siegenian onward), there was interchange of considerable parts of the turbidicolous faunas on the shallow shelf, which are more decisive for palaeozoogeographic distinctions than claricolous faunas and are more often endemic, due to adaptations to special conditions of their regions.

Also in times when both Rhenohercynicum and IberoArmorica were populated with shallow neritic benthos, differences in their palaeolatitudes (which, according to the faunas, were not too great) and differences in the degree of sediment transport and reworking and the corresponding turbidity of the filtered water caused conspicuous differences in their faunas. On the whole, there are numerous rather claricolous taxa in IberoArmorica that will not usually be found in the thick clastics of the Rhenohercynian Siegenian and Emsian and thus contribute to such faunal differences as are not due to palaeozoogeography proper. Such differences have no significance for the reconstruction of plate tectonic maps.

The characterization of the Mauro-Ibero-Armorican faunal province for shallow neritic benthos (Carls, 1988), though stressing its interior ties, should not be overinterpreted by neglecting its numerous links with the Rhenohercynicum; its concept was coined in order to stress the close geographic relation between Iberia and NW Africa against refutable postulates of wide oceans between them. Gandl (1972) has underlined the close relations of the Lochkovian trilobite genus Acastella from the Anti-Atlas via Ibero-Armorica to the Rhenohercynicum and Podolia. Of course, besides such links there exist also distinguishing elements in the brachiopod faunas (see, e.g., Lochkovian Proschizophoriinae according to Carls, 1974; some of the Howellella according to Carls, 1985, and Gourvennec, 1989) and even in the icriodid conodonts that differ in the early Lochkovian of Celtiberia and Podolia. But differences of such degree exist, transitorily, even in the brachiopod and conodont faunas of the mid-Lochkovian time within Celtiberia itself between the Nogueras area plus the Niguiella area on the Ebroian side and the eastern Guadarrama on the opposite, Castilian or Central Iberian, side of the sedimentary basin.

However, in the case of the Niguiella fauna, the presence of some taxa that seemed to be uniquely Rhenohercynian, like Siegenian Multispirifer, or typically (though not exclusively) Rhenohercynian, like Rhenorensselaeria strigiceps, is remarkable. Likewise remarkable is the concentration of Rhenohercynian taxa in Iberia under exclusion of the nearby thriving truely Ibero-Armorican taxa like the chonetids mentioned above. This association might evoke the impression of a Rhenohercynian faunal colony in an Ibero-Armorican surrounding — but that is refutable, as we will see. There must be ecologic conditions for the selection and combination of the Niguiella association, and these must be considered in the context of Siegenian palaeogeography and under aspects of palaeoecology.

\section{THE STRUCTURAL STOREYS OF THE RHENOHERCYNICUM}

As most problems that stand in our way are related to the Rhenohercynicum, introductory remarks must outline its aspects relevant for Early Devonian palaeozoogeography. The Rhenohercynicum has originally (before the plate tectonic views were introduced) been conceived as a sedimentary and structural belt of the European Variscides with north-west directed polarity, exposed along strike from north-east of the Harz through the Rhenish Slate Mountains and the Ardenne unto southern Cornwall. It is composed of variously distinguished and interconnected depocentres that have undergone a common structural development in which volcanism, folding, nappe transport and deposition of flysch were the unifying processes. It consists of three different structural storeys the distinction of which is necessary for the discussion of plate tectonic postulates. Regarding late Silurian to Emsian sedimentation, we rectify some age relations and thereby reform palaeogeographic concepts. 
1) There is a basement of Cambrian to Ordovician sediments that were only moderately affected by Caledonian movements and now crop out in several massifs. According to the presently leading plate tectonic interpretations of Variscan Europe, these materials made up the small plate of "Eastern Avalonia" that is believed by many to have docked against Baltica, thus causing the Caledonian closure of a "Tornquist Ocean". But "Avalonia" and its docking probably are mere hypotheses, because the earlier and stronger effects of Caledonian movements occurred on the wrong side, away from Baltica. Although we are not mainly concerned with this lower structural storey in this article, we must consider that the Caledonian effects on the Rhenohercynicum created a structure in the southern vicinity of its actual border, which contributed to the sediment input (coarse-grained Hermeskeil Formation, up to $1,000 \mathrm{~m}$ Taunus Quartzite). It is difficult to discuss, whether a nearby southern source area contributed also to the installation of deltaic facies (which prograded first from southern towards northern parts of the Rhenohercynicum during the early Lochkovian), because the first sedimentary regime was the marine "dumontianus Shelf" of the late Pridolian (see below).

2) The main masses of sediments exposed today in the Rhenohercynicum, were deposited in (par)autochthonous sequences of final Silurian to Carboniferous ages. As to their biostratigraphy from Pridolian to Early Emsian, there are several misunderstandings, the elimination of which leads to the following outlines that differ from current opinions in relevant details. The formation of post-Caledonian sediments began late in the Pridolian on the widely extended and still comparatively uniformous marine "dumontianus Shelf" (Carls, unpublished data; Artois, Rocroi, Gdoumont, Remscheid-Ebbe, Müsen, Taunus) with moderate accumulation rates. There are also early Early Lochkovian marine faunas in the Ardennes, but marine facies ended very soon near the southern margin (Taunus, southern Ardennes) and lasted $2 \mathrm{Ma}$ longer in the north-east (Ebbe Anticlinorium). Clastic deposition was then intensified by a moderate degree and kept the entire region deltaic for $7 \mathrm{Ma}$ (most of Late Lochkovian and Early Siegenian; thicknesses mostly below $1 \mathrm{~km}$ with local gaps). A second intensification occurred on both sides of the Rhine and lasted through Middle and Late Siegenian and the Early Emsian (totalling less than $4 \mathrm{Ma}$ ). This was combined to synsedimentary expansion and the shaping of particular depocentres (Solle, 1960) and the increase of keratophyre volcanism. Molasse of partly deltaic facies (in the north) and largely marine facies (more to the south, here with accumulation rates approaching $4 \mathrm{~km} / 1 \mathrm{Ma}$ ) was deposited, while a diverse marine fauna, resembling the Nigüella fauna and evidently coming from IberoArmorica, invaded the marine parts of the region. This invasion happened just when the accumulation switched to so high rates. Possibly, the new fauna entered via south-eastern Ardennes (Longlier fauna) in Belgium; there (and partly in the Augustenthal fauna near the Rhine, $10 \mathrm{~km}$ north of Koblenz), Leptaenopyxis,
Arduspirifer rolfwerneri nom. nud. and more frequent early Euryspirifer hint at best and more general links to Ibero-Armorica, whereas the more arenaceous facies of the Rhenohercynicum were occupied by more selected associations resembling the Nigüella fauna.

Most of the masses of the Siegenian and Emsian siliciclastics came from the Caledonides of the Old Red Continent, but the Taunus Quartzite (up to Late Siegenian) had its source area toward the south — in the direction where Caledonian effects had been stronger and where Pridolian-Lochkovian marine facies had ended first, giving way to deltaic deposition. Although not much else is known about the southern source areas, we should not be sure that they are identical with the basement units that are presently located there. When the last phase of the deposition of the Hunsruick Shale with the famous fauna of Bundenbach took place (late Zlichovian, final Early Emsian, against former age assignments) these sediment sources had ceased their supply since some $2.5 \mathrm{Ma}$, but their structure might still constitute the southern frame of the Hunsrück basin, which immediately thereafter converted itself into a land area (Solle, 1970). It seems probable that the Hunsrïck basin with its ammonoids, dacryoconarids and partly huge arthrodires had its connection with the open sea towards south-west, i.e. close to the probable inlet for the Middle Siegenian faunas in the south-eastern Ardennes.

The above image of the Rhenohercynicum in the Early Devonian implies some corrections of age assignments and applies a calibration of the time and corresponding accumulation rates and, thus, it differs from former views. The Rheno-Ardennan marine molasse is mainly concerned, when we refer below, in our palaeozoogeographic comparisons, to the Rhenohercynicum. Its marine faunas typify the Rhenish Biofacies (especially the Stadtfeld Formation of the late Early Emsian in the Eifel Hills). The Middle and Late Devonian as well as the Carboniferous history of the Rhenohercynicum need not be treated here.

It results from this history of the Rhenohercynicum, that the main reason for the sudden invasion of the Middle Siegenian fauna into the Rhenohercynicum was not the arrival and docking of an "Armorican" Arc with Ibero-Armorican fauna along the southern margin of the Rhenohercynicum, but that the fauna was already available and could occupy its new biotopes immediately in the course of the Middle Siegenian ingression.

3) Originally also included under the heading of "Rhenohercynicum", there is a third set of lesser extent which is allochthonous and has been emplaced above the second complex by nappe movements from SE towards NW. It is heterogeneous in composition, as it comprises thin formations of a starved basin with allodapic (Flinz) formations with resedimented conodonts, cherts, olistostromal masses and graywackes, all of which have undoubted southern provenances. Especially near the south-eastern margin of the Rhenohercynicum near Gießen (Lindener Mark), in positions close to the autochthonous complex and below the main mass of the Gießen Nappe, there are small bodies of fossiliferous 
Ordovician to Devonian rocks which have been interpreted as tectonic slices and/or olistoliths. It is clear that they are alien to the autochthonous storey and bear encoded messages from a southern neighbourship. Franke and Oncken (1995) used these remnants of a problematic structural history for basing on them a scenario of plate tectonics concerning the closure of a hypothetic "Rheic Ocean" with the assumed arrival of "Armorican" faunas in the Early Emsian and the immediately subsequent opening of the hypothetic "Lizard-Gießen-Southern Harz Ocean". As we have just demonstrated, the IberoArmorican faunas arrived with the Middle Siegenian ingression, thus disproving the model of Franke and Oncken (op. cit.). If this and further similar scenarios were correct, it would not be possible to array the evident relations between Early Devonian faunas in IberoArmorica and in the Rhenohercynicum in a palaeogeographic context without improbable hypotheses. Therefore we discuss some such scenarios below.

\section{DISCUSSION OF SOME PALAEOGEOGRAPHIC RECONSTRUCTIONS OF VARISCAN EUROPE}

The palaeozoogeographic framework of Palaeozoic Europe is obscured by most of the current palaeogeographic reconstructions. In order duely to locate the Nigüella fauna in it, we must first examine diverse plate tectonic postulates which claim that various wide oceans impeded the exchange of Early Devonian faunas between Ibero-Armorica and Rhenohercynicum and which have used palaeontologic information misleadingly. However divergent such postulates are, they use to start from distributions of fossils as highly significant data, and so will we - only more carefully. Being parsimonious enough, a model must imply the pretectonic array of the belts of sedimentary facies and faunal geography which the palaeontologic data warrant. Controlable biostratigraphic data and interpretative structural zonation are combined in current rather liberal hypotheses about the Variscan history of Europe. Too often, only a few misunderstood initial palaeontologic hints are available; the less precise they are, the more schematically they will be exploited in the standard scenarios of drifting, collision, and rifting. If the geographic distribution of faunas has any meaning at all for plate tectonics, then the relations between our seemingly endemic fauna of the shallow arenaceous shelf at Nigüella, just south of the Ebroian Massif, and its slightly younger kinship in the shallow Rhenohercynicum must truely be significant for finding out what was, in Siegenian time, the array of rising source areas and subsiding troughs that directed the migrations of our fauna and would later be converted into structural belts.

As regards Ibero-Armorica, the models presented by Ziegler (1988: text-fig. 3: Pridolian, 4: Emsian) are erroneous in separating identical shallow neritic benthos in Armorica (in the north) from Iberia (in the south) by means of a wide "Rheic Ocean"; they likewise err in separating Iberia from north-west Africa through the "Proto-Tethys" and "Proto-Atlantic"; Ziegler's model splits the Mauro-Ibero-Armorican shallow neritic faunal subprovince into three separate parts. The correspondences in shelly faunas and even in lithologies of near-shore sediments within the Mauro-Ibero-Armorican faunal province stand against Ziegler's models, which also err in placing a coeval "active foldbelt" through Iberia just beside our undisturbed Celtiberian sedimentary facies of the study area without any synorogenic feature and only chemically mature detritus. A faunal interchange between Armorica and the Rhenohercynicum would easily be allowed by Ziegler's model, but it would exclude Iberia and the Nigüella fauna from the communication with the Rhenohercynicum and Armorica.

\section{Plate I.}

All specimens are from Nigüella; southern slope of Alto de la Cruz, float about $20 \mathrm{~m}$ below top of Santa Cruz Formation. Scale bar $=1 \mathrm{~cm}$.

1-3 Acrospirifer aff. primaevus (Steininger, 1853). 1. Pedicle valve (MPZ 98/464). • a. Deformed Steinkern, ventral view. Note gonoglyphe. Radiating striation of diductor fields has eliminated the longitudinal striation. - b. Postero-ventral view. Note free remnants of tooth plates. • 2. Pedicle valve (MPZ 98/465). • a. Deformed Steinkern, ventral view. • b. Outer mould. Note intrasinal costa. - 3. Juvenile pedicle valve (MPZ 98/466). • a. Steinkern, ventral view. • b. Replica of outer mould. Intrasinal costa indistinct, but present.

\section{4, 5 Multispirifer cf. solitarius (Krantz, 1857). 4. Pedicle} valve (MPZ 98/467). • a. Steinkern; incomplete. • b. Replica of outer mould. On the left flanc, the fascicostate sculpture is preserved, elsewise, it is abraded. - c. Outer mould. - 5. Pedicle valve (MPZ 98/468). Outer mould. Fascicostate ribbing.
6 Mauispirifer gosseleti (Beclard, 1887). (MPZ 98/469.) - a. Steinkern. • b. Outer mould.

7 ? Tenuicostella sp. Steinkern of pedicle valve (MPZ 98/470).

8-11 Rhenorensselaeria strigiceps (Roemer, 1844). 8. Steinkern of closed shell (MPZ 98/471). • a. Posterior view; ventral valve downside. Short dental plates. Left tooth in socket. - b. Right lateral view; ventral valve downside. - c. Posteroventral view. Note dorsally diverging short slits according to tooth plates. $-\mathrm{d}$. Posterodorsal view. - 9. Steinkern of ventral valve (MPZ 98/472), slightly posteroventral view. Strong median ridge mainly behind diductors. - 10. Steinkern of brachial valve (MPZ 98/473), dorsal view. Cardinal process developed. - 11. Steinkern of ventral valve (MPZ 98/474), slightly posteroventral view. Gonoglyphe developed. 
Plate I

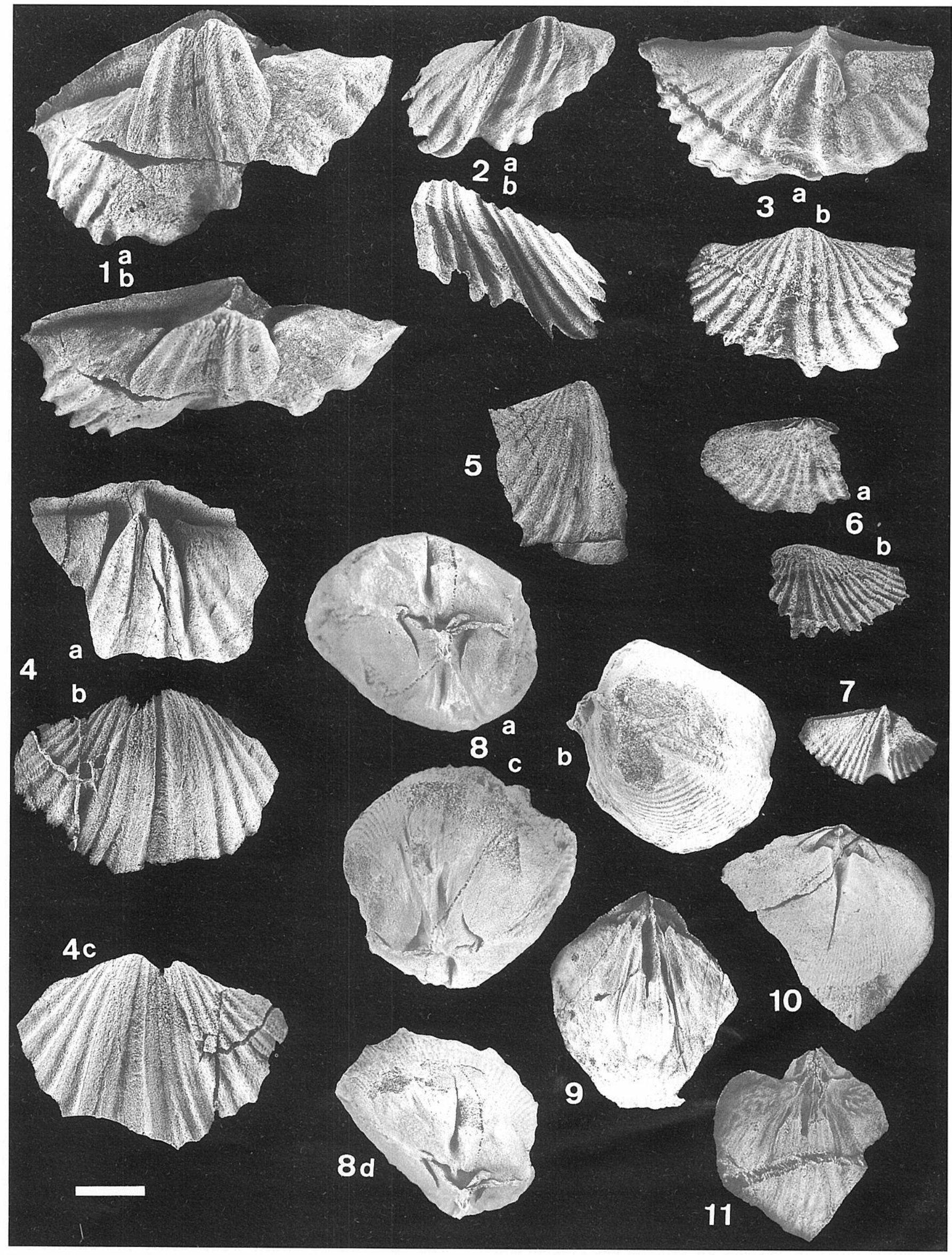

Revista Española de Paleontología, nº extr. Homenaje al Prof. Gonzalo Vidal, 1998. 
Smith (1996: 160, text-fig. 12: Silurian/Devonian boundary) has Armorica and its eastern annexes docked with East Avalonia-Baltica, etc. already in Silurian time. He keeps Iberia separated from Armorica through a "part of Iapetus" whose waves washed southern, not (north)western Baltica, where we would have sought them some time before. Still quoting Ziegler, Smith's model, herein even surpassing Ziegler's, disregards the classic structural subdivision of Variscan Iberia and does not consider the Early Devonian faunal relations of Iberia with Africa and Armorica. Therefore, Smith's model can be neglected in context with our theme and in context with probable structures of Palaeozoic Ibero-Armorica.

As already mentioned briefly, Franke and Oncken (1995) developed a dramatic scenario of the closure of the "Rheic Ocean" (not following Ziegler, they preferred to place it north of their "Armorica") with immediately following opening of the likewise hypothetic "Gießen Ocean" along the same suture. They supposed that in a collision of "Armorica" against "Avalonia", which was already docked south of Baltica, small fragments from "Armorica" including the brand-new Steinberg Limestone (Guerichina strangulata dacryoconarid Zone, final Pragian in the original sense) with its assumedly distinctive "Armorican" plancton were placed above the Rhenohercynicum near Gießen (Lindener Mark). Immediately thereafter, the "Gießen Ocean" should open, where the Rheic had just disappeared, the ErbslochGrauwacke should be sedimented with its supposedly Rhenish fauna near the "Avalonian"=north-western margin of the new rift, and the Steinberg Limestone should be incorporated in an olistostrome. (The ErbslochGrauwacke s. s. is a fossiliferous deposit in the Kellerwald of early Early Emsian age in classic sense; it has doubtless equivalents in the Harz, etc., as described by Jahnke 1971; however, near Gießen, where it would be important for Franke and Oncken's view, only its lithofacies, but not its fauna is known; its Celtiberan age equivalent in different facies is early in step Spir.22 of the calibration by Carls in Weddige, 1996: 277.) Faunal differences between the Rhenohercynicum and the "Armorica" of Franke and Oncken (including the Barrandian, but disregarding the Iberian faunas) were believed to have existed before the collision, but to have vanished due to it. At the time of the Nigüella fauna, only some $2 \mathrm{Ma}$ before the supposed beginning of the rifting of the Gießen Ocean, the approach of "Armorica" towards "Avalonia", in the scenario of Franke and Oncken (1995), would have been already rather close, and thus, it might seem that the invasion of the Siegenian fauna and that scenario are in full harmony. Often enough are false evidences combined in such a way.

However, the scenario by Franke and Oncken (1995) is quite impossible to have occurred: plancton organisms like Guerichina cannot be used to distinguish plates, because they may be too widely distributed in oceans. Shallow neritic benthos is more suitable. - The ages of the Steinberg Limestone and of the Erbsloch-Grauwacke are hardly different, because the original late Pragian and the classic early Early Emsian are not in sequence, but they overlap by just the entire G. strangulata Zone; the Erbsloch-Grauwacke as well as its faunistic equivalents in Germany and its age equivalents in the Nogueras area are also in the late part of the $G$. strangulata Zone and in the final part of the range of Acrospirifer fallax. (The entire G. strangulata Zone in the Barrandian concerns only about $3 \mathrm{~m}$ nearly topmost beds out of the total of $160 \mathrm{~m}$ of Pragian strata; "measured" in steps of evolution, it comprises less than $0.7 \mathrm{Ma}$ according to Carls, unpublished data).

The concentration of all the following events, as postulated by Franke and Oncken (1995), is too much action for too short an interval within the G. strangulata Zone: 1) Sedimentation of the Steinberg Limestone with claricolous shelly fauna and pelagic dacryoconarids; 2) collision and overthrusting without destroying the thin layer of fresh Steinberg Limestone that was first at the surface of the "Armorican" terrane and then at the surface of "Avalonia"; 3) continuous non-flysch sedimentation in the underlying "Avalonian" terrane (not alluded to by Franke and Oncken, but actually going on);4) initial aperture of a new ocean; and 5) deposition of collisionplus rift-produced detritus (Erbsloch-Grauwacke) and of olistostromes (with Steinberg Limestone, etc.) in the new ocean.

The fossiliferous Erbsloch-Grauwacke was certainly not deposited under the influence of the Rhenohercynicum; its partly claricolous fauna has mostly IberoArmorican characters, especially in its Arduspirifer [Carls (1987: 83); the specimens of Jahnke (1971: pl. 9, figs. 1-2) from the Harz belong to an unnamed taxon existing in Celtiberia and in Armorica, figured by Gourvennec (1989: pl. 18, figs. 32-36; pl. 19 figs. 1, 5, 78) as "Arduspirifer extensus (Solle)"]. The alignment of "Armorican" and Rhenohercynian shelly faunas in the Emsian, which Franke and Oncken (1995) assumed as their faunistic proof for the closure and collision and which they unduely exemplified with the not too Rhenish Erbsloch-Grauwacke, was not so thorough as to wipe out all distinctions. - Supposing that "Armorica" nestled against "Avalonia" in a collision that ended the Rheic Ocean, there would rise a question, which Franke and Oncken do not even mention: when the thrusting should happen near Gießen, where was, at that time, the southeastern source area located that furnished up to $1,000 \mathrm{~m}$ of Taunus Quarzite up to the Late Siegenian? - Franke and Oncken do not explain, how the pattern of spatially restricted basins in the Rhenohercynicum (Solle, 1960) could fill with up to $4,000 \mathrm{~m}$ of Middle plus Late Siegenian marine clastics in about $1 \mathrm{Ma}$ (during still moderate, but progressive development of the Rhenish Keratophyre Volcanism) under a compression, which the assumed approach of the "Armorican" plate would have caused. Franke (1992: 169) was already aware of this problem and envisaged "that the Rheno-Hercynian basement, during its northward drift, overrode the spreading axis of Tornquist's Sea and underwent extension ...". Franke neglected that the margin of Baltica was covered by south-westwardly increasing and deepening sediments so that structures in a (likewise only 
hypothetic) Tornquist Sea would have had a northwest strike, but that the Rhenohercynicum would have needed a spreading axis striking north-east in order to make its basins sink. (By the way: in the Silurian and earliest Devonian there was a sea south-west of Baltica with distally increasing depth and sediment thicknesses; through its shallower zones, the Pridolian to Lochkovian faunas of the Rhenohercynicum were connected with Podolia. But there is no need to assume an oceanic spreading centre for this basin which only followed the old margin of the platform of Baltica.)

The model of Franke and Oncken (1995) is the most detailed one of those discussed here, but it simply errs in the application of the stratigraphic stages and in most of its faunistic argumentation concerning the Early Devonian, and thus it ends postulating even structural impossibilities. Therefore, its hypothetic assumption of the Rheic Ocean and its closure cannot interfere with our observations of actually existing faunas. We negate an effective oceanic barrier for shallow neritic faunas between Ibero-Armorica and the Rhenohercynicum. As such did not exist before the Emsian, it could not be closed toward the beginning of the Emsian, and therefore the other events could not follow - the less so, because there was by far not enough time for all the postulated dramatic happenings.

The above plate drift and rift models can stand for so many others. Many are multiplied by quotations of too credited but unwarranted foregoing models. Our discussion should have made clear that such geologic modelling under oportunistic misuse of fossils cannot constitute a serious obstacle for sound palaeozoogeography.

The considerations of Robardet et al. (1993: 686-687, text-fig. 1/B3) are by far more adequate, but they also require some modifications. These authors rely strongly on faunal aspects. They strictly (and rightly) insist in the direct connection of facies and fauna during the Ordovician between the East Lusitanian-Alcudian Zone in southern Iberia and the "Domaine médio-nord armoricain". However, nearly the same is valid for Celtiberia in the Ordovician and includes it in the same, still broad and undivided Ibero-Armorican basin. Subsequently, this basin was progressively subdivided. For the further structuration, it is even more important that, in the Pridolian and Early and Middle Devonian, the same "Domaine médio-nord armoricain" had its doubtless continuation in the West Asturian-Leonese Trough unto Celtiberia, whereas the connection and former similarity with the East Lusitanian-Alcudian Zone has diminished. Carls (1988) has shown a way to reconcile Ordovician and Devonian facts under one model. Under this premise, many of the arguments of Robardet et al. (1993) can be accepted; but only to consider the Ordovician aspect is misleading, because the structural development went on and the progressive growth of a longitudinal barrier in the basin [but not the "active fold belt" claimed by Ziegler (1988: 19, text-fig. 3-4), misquoting Carls, 1983] led to a different situation in the Early Devonian. The latter is relevant for our
Niguiella fauna: a community that is found in Celtiberia, could likewise have congregated in Armorica (although the same selection has not yet been found there), and its members could reach the Rhenohercynicum from there, together or even one by one, as soon as the Rhenohercynicum offered suitable biotopes. If however, the palaeogeographic reconstructions like that of Franke (1992) prefer to bend the prolongation of the West Asturian-Leonese Trough "down" towards Aquitania and disconnect it from Armorica, they must also prove that the faunal exchanges we demonstrate did not occur.

The faunal relations between the Rhenohercynicum ("Ardenne" of Robardet et al., 1993: 689) and IberoArmorica (which these authors discuss) should be revised to some degree in the light of the following conditions. Firstly, Robardet et al. (op. cit.) emphasize pre-Emsian faunal differences between Ibero-Armorica and Rhenohercynicum, whereas we want to rely more on the existing faunal similarities from late Silurian onward, although we also recognize differences. It is a matter of degree: Craniops, Baturria edgelliana ssp., Salopina missendenensis (Straw, 1933), Salopina e.g. lunata (Sowerby, 1839), Shaleria, Strophochonetes, and Howellella elegans (Muir-Wood, 1925) are a great percentage of the late Silurian brachiopods in Celtiberia, and they are shared by Ibero-Armorica (largely Celtiberia) and the ensemble of Baltica-Rhenohercynicum-England with at least generic or even with specific identity. That this list is not longer, is largely due to the general scarcity of late Silurian brachiopod faunas in Ibero-Armorica. A few materials are still unstudied. After all, expressed in percentages of shared taxa, the relations in the late Silurian between Ibero-Armorica as a whole and the so-called "Avalonia" would not be too poor. In the early Lochkovian, there are, indeed, more distinguishing than common species; but there is a number of common genera. Common taxa are: Podolella rensselaeroides KozXowski, 1929, Mutationella barroisi (Asselberghs, 1930), Howellella mercurii tota sp., Protathyris, Mesodouvillina, Iridistrophia, Protocortezorthis, Fulcriphoria havliceki Carls, 1974, and the sequence of Acastella (see Gandl, 1972). The absence from Celtiberia of genera like Leptaena, Atrypa and Bathyrhyncha in the early Lochkovian is possibly due to biofacies, because these Rhenohercynian genera are usually associated in faunas of high diversity (e.g., Hüinghausen Formation); however, their lack even in Lochkovian limestones of the eastern Guadarrama is remarkable. So is also the vicariance of Proschizophoria falsa interpres Carls, 1974 that lived in Ibero-Armorica and in Nova Scotia (Meguma Zone) and Proschizophoria torifera (Fuchs, 1919) that lived in the Rhenohercynicum.

Goujet (in Blaise et al., 1991: 180) has stressed that the presence of three thelodont vertebrates in the midLochkovian of Celtiberia indicates close relations with the Welsh Borderland. Even if thelodonts are not so restricted to deltaic environments as has often been claimed (we find Siegenian scales of Turinia in open shelf areas in Celtiberia), they may plead for close connections, viable for moderate swimmers, of the 
shallow seas of Ibero-Armorica with the southern margin of the Old Red Continent (Laurussia).

Robardet et al. (1993: 687) are right in stating that from the "upper Pragian onward" ... in a "period of very marked endemism", the faunal differences between Ibero-Armorica and the sea at the southern margin of the Old Red Continent began to fade. But they did not consider that during $7 \mathrm{Ma}$ before the classic Middle Siegenian there were neither marine shelly faunas in the Rhenohercynicum nor suitable environments for deltaic vertebrates in Ibero-Armorica (vertebrate research is now bridging the former lack in information to some extent). In reality, the seeming differences consist in lack of comparable facies and faunas, but not in contrasting populations.

That Ibero-Armorican and Rhenohercynian faunal elements of the Early Devonian could get together, has recently been documented by Bouyx et al. (1992) in the Meguma Zone of the Canadian east coast, completing first hints by Boucot (1960). Such relations make it unnecessary to work with hypotheses of wide oceans and their closure, whenever changes in the compositions of faunas are assumed and when seemingly suitable magmatic events, etc. can be related to them.

There is still another structural problem within the Ibero-Armorican complex, independent of surrounding hypothetic oceans. It concerns the due alignment of structural belts from Iberia across the Biscay into Armorica and the Lizard Complex. Franke (1992: text-fig. 2), differing from Robardet et al. (1993: text-fig. 3, discussed above), even connects the Ossa-Morena Zone (instead of the East Lusitanian-Alcudian Zone) with the "Domaine médio-nord armoricain" of the latter authors. His reconstruction of sedimentary and structural belts neglects the westward polarity of the Variscan folding in the eastern Guadarrama and places our study area in a "presumed extent" of "lower Carboniferous" "synorogenic clastics" of a foreland basin, although there is no Early Carboniferous, but a Namurian flysch. With other words: as to Ibero-Armorica, Franke's scheme implies doubtful data. Beyond them, it leaves Celtiberia in a position relative to Armorica and to the Rhenohercynicum that would make efective interchange of shallow neritic benthos among the three regions impossible - the more so, if Franke's concepts of former oceans, as shown in other publications, are also taken into acount. Looking out from the "Avalonian" Rhenohercynicum, the latter condition would place Celtiberia of the Early Devonian originally on the southerly side of the structural belt "Massif-Central-Moldanubicum" and, consequently, beyond the hypothetic ocean of the same name (see also Franke and Oncken, 1995: text-fig. 1). This would make close faunal relations between Nigüella and the Rhenohercynicum quite difficult and improbable. As long as structural schemes do not provide viable faunal and facies connections for shallow neritic benthos along sedimentary troughs that later grade into structural belts, such often repeated models should better not be considered.

Structural geologists, attempting plate tectonic solutions for structural problems concerning the Palaeozoic, often start from incomplete and arbitrarily selected palaeozoogeographic informations. E.g., probably swimming trilobites like Selenopeltis and Cyclopyge are applied in order to establish close palaeozoogeographic relations between British "Avalonian" and other "Gondwanan" regions in the Ordovician and to derive plate tectonic situations from their distributions. However, if these trilobites swam as (hemi)necton in deeper distal offshore waters, they would be rather independent of coastal substrate conditions and of climate at the ocean surface, but might be transported by currents even across broader oceans. In such case, they would not demonstrate palaeogeographic vicinity and definite latitudes and would discredit the Ordovician maps based on them. As to the Devonian, Dacryoconarida should likewise be recognized as widely distributed plancton and as excellent age indexes and also as indicators of a minimum depth of about $30 \mathrm{~m}$, but they should by no means be misused for the distinguishing characterization of drifting plates, as Franke and Oncken (1995: 59) did.

McKerrow (1994) remarks that "Early Devonian (preEmsian) freshwater fish are identical north and south of the Rhenohercynian (they occur in south Devon and the southern Taunus)", so that a "compressional event" of Emsian age would forbid "that the Rhenohercynian basin opened" earlier. Although we do not want to interfere with all details of this argumentation, we suggest to consider that certain primitive vertebrates, although their remains are mostly obtained from deltaic facies, could possibly swim well enough to spread in their youth or even at maturity even across a mini-ocean. Their spreading around the Old Red Continent and along the northern rim of Gondwana from delta to delta was only possible if they could cover large distances in seawater. Therefore, McKerrow's fish argument has no bearing for the timing of the opening of the "Rhenohercynian Ocean", because the vertebrates might as well have swum around or across the narrow basin, if it had opened already in pre-Emsian time. If McKerrow's fish-induced argument could really warrant a compressive Caledonian regime up to the Emsian also for the Rhenohercynicum, the deposition of the enormous thicknesses of Middle Siegenian to Early Emsian mostly marine sediments with increasing Emsian keratophyric volcanism would be inexplicable and the invasion of the Niguiella fauna into the Rhenohercynicum would not have taken place. But it did.

In any case, in the Taunus, the marine strata of the late Pridolian "dumontianus Shelf", the following deltaic sediments with vertebrates and the shallow marine Taunus Quartzite (Siegenian) form an indivisible sequence that would admit the "Rhenohercynian Ocean", which McKerrow (1994) sought, only in a more northern position than the Taunus, i.e. within the Rhenohercynicum. However, Franke and Oncken (1995: text-fig. 3) place their "Rhenohercynian Ocean" just south of the southern Taunus, marginally outside the Rhenohercynicum, and they apply the additional name "Lizard-Gießen-Sïdharz- 
Ozean" to it. To locate hypothetic oceans and related structures under identic or changing names at changing positions is a confusing, but common habit in plate tectonics. However, it is not habitual to recognize and to comment on such discrepancies in order to reduce the confusion.

Likewise, it is a habit to develop structural scenarios that are not concordant with the observed development of sedimentary facies and fossil populations. How can due discussions of such discrepancies be neglected? The detailed succession of rather particular shallow shelf sediments with very characteristic associations of fossils from Celtiberia around the Cantabrian Knee and into middle and northern Armorica from Pridolian to Givetian time presents, along strike, by far the closest internal similarities of all facies belts in Variscan Europe. If such chancy arguments, as we have criticized above, are founded on arbitrarily selected fossils, why then is the available ample and solid palaeontologic information not made use of? Actually, it is not taken into account by most influential structural geologists. It appears to be more profitable to array rough radiometry, doubtful palaeolatitude data, structural polarities, metamorphism, and geochemistry of magmatic rocks in palaeogeographic and structural hypothesis, although the results of biostratigraphy stand against them. Necessary rearrangements of palaeogeographic and structural scenarios should not only reconcile the diverging nomenclatures of oceans and terranes, but they also must accord with the sensitive pattern of shallow neritic lithoand biofacies and faunal composition of early preorogenic phases of the basin history.

\section{THE ORIGIN AND THE ASSEMBLY OF THE NIGÜELLA FAUNA}

In first line, the Niguiella fauna must not be considered as invasors coming from the Rhenohercynicum, but all on the contrary. As it is slightly older than the invasion of the Siegenian Rauhflaser fauna into the Rhenohercynicum, we must rather consider it as a community that lived already at Niguiella (and possibly at unknown other, ecologically similar localities along the Ibero-Armorican Trough) under conditions which it would find little later also in the Rhenohercynicum. This fauna at Niguiella was certainly recruited in Celtiberia, but very probably, it could likewise have come together in Armorica during about that age. It is in great parts of Ibero-Armorica, where we find earlier appearances of the typical Rhenish Middle Siegenian taxa or where we can trace the ancestors and/or origins of many typical taxa of the Rhenohercynian Middle Siegenian. This concerns Rhenorensselaeria strigiceps (the earlier species $R$. crassicosta Koch, 1881 is not congeneric and may have a different origin), Meganteris, Vandercammenina, Mauispirifer gosseleti, Euryspirifer dunensis, Acrospirifer primaevus, Leptaenopyxis (only faunas of Longlier and Augustenthal which are also richer in Euryspirifer), Boucotstrophia herculea, Platyorthis circularis, Schizophoria provulvaria, and Proschizophoria personata (Zeiler, 1857) (some of these, including the latter two, have not yet been identified at Niguiella). Also some trilobites (Burmeisterella in fauna d3b-beta-2 of the Santa Cruz Formation, Treveropyge of the prorotundifrons stock in d3b-gamma) and a few remarkable lamellibranchiates (big Goniophora from d3b-beta-2 onward, Limoptera orbicularis (Oehlert, 1888) high in d3b-gamma) that became most important in the Middle Siegenian of the Rhenohercynicum, once they found marine conditions there, have Ibero-Armorican roots (but are not yet known from Nigüella).

The origin of the most prosperous Rhenohercynian Emsian spiriferid genus, Arduspirifer was also in IberoArmorica. Its first species was Arduspirifer rolfwerneri nom. nud. that appears in the basal beds of submember d3b-gamma of the Santa Cruz Formation near Nogueras and has been figured by Gourvennec (1989: pl. 18, figs. 1-15) from middle parts of the Montguyon Formation in eastern Armorica as "Arduspirifer prolatestriatus Mittmeyer, 1973". Vandercammen (1963: 87) mentioned three specimens of "Euryspirifer arduennensis" from the Middle Siegenian Quartzophyllades de Longlier in southeastern Belgium; they also belong to this A. rolfwerneri nom. nud., which ends at the top of the Santa Cruz Formation. It is noteworthy, that just after its origin (derivable from Hysterolites salicamensis Gourvennec that occurs in the upper fauna d3b-beta-2 of the Santa Cruz Formation) and after spreading through IberoArmorica, this taxon also arrived in the Rhenohercynicum, where it was, however, not so successful, so that the genus disappeared from the Rhenohercynicum until its come back with true $A$. prolatestriatus at the beginning of the classic Emsian. It might be significant, that at Longlier also Leptaenopyxis is found as a messenger from Ibero-Armorica and Barrandium that also had a limited distribution in the Rheno-Ardennan region; possibly the southern Ardenne was comparatively well connected with the entry of the Ibero-Armorican invasors.

Possibly due to the extraordinary attention that the Rhenish faunas have received in the earlier research, it has usually been looked out, where first Siegenian or Emsian envoys from the Rhenohercynicum might turn up. But in Early Siegenian times, the deltaic Rhenohercynicum could not be a source of shelly faunas. Also McKerrow (1994) claimed that the first arrival in "the Armorican parts of Gondwana" of "northern ostracodes" without planctic larvae, and therefore unable to cross an ocean, was in Emsian time and documented the final closure of the Rheic Ocean. However, the age of Spanish beyrichiids found by Robardet et al. (1991) in Sierra Morena is not classic Emsian, but late Early Siegenian, slightly older than the Nigüella fauna, being an equivalent of the basal layers of submember d3bgamma of the Santa Cruz Formation. Moreover, beyrichiids like Zygobeyrichia abounded in Celtiberia already since mid-Lochkovian time, and therefore the finds from southern Spain are not at all significant in the plate tectonic sense assumed by McKerrow. 
Whatever the reasons for the composition of the Nigüella fauna were, they could not be due to a sudden disappearance or bridging of a former oceanic barrier for planctic larvae between "Armorica" and "Avalonia" of Franke and Oncken (1995) and in the sense of McKerrow (1994), because already parts of the Pridolian and Lochovian neritic benthos prove that such barrier did not exist. What existed, were different life conditions in different sedimentary settings. Carls (1985: 302-309) has discussed the latter as to their influence on the faunas; concerning the Middle and Late Siegenian of the Rhenohercynicum, Carls's (1985) model must now be completed by the new aspect that the time comprised in these intervals was much shorter than had been supposed before.

As immigration of the Niguiella faunal association into Celtiberia and entire Ibero-Armorica need not be considered, because all its taxa (except Multispirifer and Arbizustrophia) were already living there or had their ancestors there, the problem to solve only is: what did cause their assemblage at a special biotope and what did withhold the more common taxa of the wider region from this assemblage?

We have no definitive answer as to the entire fauna. Only concerning the spiriferids, there is a remarkable feature: Acrospirifer, Multispirifer and Mauispirifer, which are the dominant spiriferids, all have capillate microsculptures, whereas papillate patterns as in Hysterolites and Corylispirifer have not been realized. Gourvennec (1989) and Carls et al. (1993: 234-235) have suggested that the microsculpture supports the setae of the mantle margins and thus informs about the density and replacement modus of the setae. The comparatively coarse patterns with low divergence and, therefore, slow replacement rates of setae suggest either a high tolerance for silt in the filtered water combined to a high capacity to expulse (pseudo)faeces (might apply especially for Acrospirifer with its high dorsal median fold), or a usually low content of silt in the waters above the fairly washed substrate. Hysterolites, Corylispirifer and Arduspirifer would, according to this model, be more apt for the exclusion of silt from the mantle cavity and dominate less winnowed substrates. The presence of Pleurodictyum and "Favosites" agrees with scarcity of finest suspensions in spite of intense hydrodynamics. The Nigüella fauna does not seem to have been extremely turbidicolous, although it might resist transport of rapidly settling sand. The same may be said about German Middle Siegenian faunas of the Seifen type that include tabulates. Accumulation rates and habitual degree of turbidity are not in proportion.

\section{CONCLUSIONS}

A brachiopod fauna from a level high within the Santa Cruz Formation near Nigüella (Eastern Iberian Chain) is bracketed by conodont faunas: just below it, there is the association of Icriodus curvicauda and of the last $I$. angustoides angustoides, and $20 \mathrm{~m}$ above it, there are
Polygnathus excavatus and I. sigmoidalis, which mark the base of the Mariposas Formation. Mainly Acrospirifer aff. primaevus correlates the Niguiella fauna with a level high within submember d3b-gamma of the Santa Cruz Formation of the Nogueras area of the same cordillera and with beds bearing the same taxon in the Armorican Massif, which is in harmony with the conodont correlation.

The association of brachiopods resembles most closely those in the largely arenaceous Mittlere SiegenSchichten in the Siegerland (Germany). Occurring in an alternation of sandstones with arenaceous shales, it had a biotope like the similar faunas in the Rhenohercynicum, with intense hydrodynamics but moderate silt suspension. The Niguiella fauna is distinguished from coeval faunas in Ibero-Armorica through its lack in most of those taxa that usually dominate the brachiopod faunas. Most of its taxa have older occurrences or ancestors in Ibero-Armorica, therefore the special composition of this fauna results to be a selection under special ecologic conditions.

After $7 \mathrm{Ma}$ of a deltaic regime, the Rhenohercynicum experienced a phase of accelerated accumulation under extension, which also induced the change to marine facies at the beginning of the classic Middle Siegenian. This was the occasion for the taxa of the Niguiella fauna to invade the Rhenohercynicum immediately, coming from Ibero-Armorica. No closure of a hypothetic "Rheic Ocean" was the reason for the invasion. Several scenarios of Mid-Palaeozoic plate tectonics seemingly stand against the above concept, however they can all be disapproved. Such scenarios misuse arbitrarily selected fossils for unwarranted hints at palaeozoogeographic situations, but are unable to incorporate evidence from early phases of shallow sedimentary basins and accurate biostratigraphy.

\section{ACKNOWLEDGEMENTS}

This paper is a result of our joint research financially supported by the Alexander von Humboldt-Stiftung. We thank Jenaro García-Alcalde (Oviedo) and Miguel Pardo (Valencia) for their critical opinions. We also thank Rodolfo Gozalo (Valencia) for technical comments on figures and text. This paper is a contribution to IGCP 421 "NorthGondwana Mid-Palaeozoic Bioevent/Biogeography patterns in relation to crustal dynamics". This manuscript had the benefit of painstaking editorial work by J. A. Gámez Vintaned (Badajoz).

\section{REFERENCES}

Archiac, A. de and Vernuil, E. de. 1842. On the fossils of the older deposits in the Rhenish provinces. Transactions of the Geological Society of London, 6 (2), 303-408.

Asselberghs, E. 1930. Description des faunes marines du Gédinnien de l'Ardenne. Mémoires du Musée Royal d'Histoire Naturelle de Belgique, 41, 1-73.

Béclard, F. 1887. Fossiles coblenziens de St.-Michel, près de St.-Hubert. Bulletins de la Société Belge de Géologie, de Paléontologie et d'Hydrologie, 1, 60-97. 
Béclard, F. 1895. Les Spirifères du Coblenzien Belge. Bulletins de la Société Belge de Géologie, de Paléontologie et d'Hydrologie, 9, 129-240.

Blaise, J., Bouyx, E., Goujet, D., Le Menn, J. et Paris, F. 1991. Le Silurien Supérieur de Bear River (Zone de Meguma, Nouvelle Écosse): Faune, Biostratigraphie et implications paléogéographiques. Geobios, 24 (2), $167-$ 182.

Bouyx, E., Blaise, J., Brice, D., Gourvennec, R., Lardeux, H. et Le Menn, J. 1992. Implications paléogéographiques des affinités nord-gondwaniennes et rhénanes des faunes dévoniennes de la zone de Meguma (Appalaches septentrionales). Comptes Rendus de l'Académie des Sciences de Paris, série II, 315, 337-343.

Boucot, A. J. 1960. A new Lower Devonian stropheodontid brachiopod. Journal of Paleontology, 34 (3), 483-485.

Carls, P. 1974. Die Proschizophoriinae (Brachiopoda; Silurium-Devon) der Östlichen Iberischen Ketten (Spanien). Senckenbergiana lethaea, 55 (1/5), 153-227.

Carls, P. 1975. Zusätzliche Conodonten-Funde aus dem tieferen Unter-Devon Keltiberiens (Spanien). Senckenbergiana lethaea, 56 (4/5), 399-428.

Carls, P. 1983. La Zona Asturoccidental-Leonesa en Aragón y el Macizo del Ebro como prolongación del Macizo Cantábrico. In: Libro Jubilar J.M. Ríos, 3. (Coord. J. A. Comba). I.G.M.E., Madrid, 11-32.

Carls, P. 1985. Howellella (Hysterohowellella) knetschi (Brachiopoda, Spiriferacea) aus dem tiefen UnterGedinnium Keltiberiens. Senckenbergiana lethaea, 65 (4/6), 297-326.

Carls, P. 1987. Ein Vorschlag zur biostratigraphischen Redefinition der Grenze Gedinnium/Siegenium und benachbarter Unter-Stufen. Courier Forschungs-Institut Senckenberg, 92, 77-121.

Carls, P. 1988. The Devonian of Celtiberia (Spain) and Devonian paleogeography of SW Europe. In: Devonian of the World. (Proceedings of the 2nd International Symposium on the Devonian System, Calgary 1987). (Eds. N. J. McMillan, A. F. Embry and D. J. Glass). Canadian Society of Petroleum Geologists Memoir, 14 (1), 421-466.

Carls, P. und Gandl, J. 1969. Stratigraphie und Conodonten des Unter-Devons der Östlichen Iberischen Ketten (NE Spanien). Neues Jahrbuch für Geologie und Paläontologie, Abhandlungen, 132 (2), 155-218.

Carls, P. and Valenzuela-Ríos, J. I. 1997. kitabicusboundary; late original Pragian, Emsian, Zlichovian; Pol. excavatus Zone; intra-Emsian substage boundary. Subcommission on Devonian Stratigraphy Newsletter, 14, 6-7.

Carls, P., Jahnke, H., Lusznat, M. and Racheboeuf, P. 1982. On the Siegenian Stage. Courier Forschungs-Institut Senckenberg, 55, 181-198.

Carls, P., Meyn, H. und Vespermann, J. 1993. Lebensraum, Entstehung und Nachfahren von Howellella (Iberohowellella) hollmanni n. sg. n. sp. (Spiriferacea; Lochkovium, Unter-Devon). Senckenbergiana lethaea, 73 (2), 227-267.

Dahmer, G. 1934. Die Fauna der Seifener Schichten (Siegenstufe). Abhandlungen der preußischen geologischen Landesanstalt, Neue Folge, 147, 1-91.

Drevermann, F. 1904. Die Fauna der Siegener Schichten von Seifen unweit Dierdorf (Westerwald). Palaeontographica, 50 (6), 229-287.

Franke, W. 1992. 6.3. Phanerozoic structures and events in Central Europe. In: A continent revealed. The European Geotraverse. (Eds. D. Blundell, R. Freeman and S. Mueller). Cambridge University Press, Cambridge, 164180.

Franke, W. und Oncken, O. 1995. Zur prädevonischen Geschichte des Rhenohercynischen Beckens. Nova Acta Leopoldina, Neue Folge, 71 (291), 53-72.

Fuchs, A. 1904. Die unterdevonischen Rensselaerien des Rheingebietes. Jahrbuch der preußischen geologischen Landes-Anstalt , 24 (für 1903), 43-53.

Fuchs, A. 1919. Beitrag zur Kenntnis der Verse- und der Hobräcker Schichten des sauerländdischen Faziesgebietes. Jahrbuch der preußischen geologischen Landes-Anstalt , 39 (1), 58-95.

Fuchs, G. 1982. Upper Siegenian and Lower Emsian in the Eifel Hills. Courier Forschungs-Institut Senckenberg, 55, 229-256.

Gandl, J. 1972. Die Acastavinae und Asteropyginae (Trilobita) Keltiberiens (NE-Spanien). Abhandlungen der senckenbergischen naturforschenden Gesellschaft, 530, 1-184.

García-Alcalde, J. L. 1972. Braquiópodos devónicos de la Cordillera Cantábrica. 4) Arbizustrophia n. gen. (Strophomenida, Strophodontacea). Breviora Geológica Astúrica, 16 (4), 56-64.

García-Alcalde, J. L. 1992. El Devónico de Santa María del Mar (Castrillón, Asturias, España). Revista Española de Paleontología, 7 (1), 53-79.

Giebel, C. 1858. Die silurische Fauna des Unterharzes. Zeitschrift für die Gesammten Naturwissenschaften, 1, 119.

Godefroid, J. and Stainier, P. 1982. Lithostratigraphy and biostratigraphy of the Belgian Siegenian on the south and southeast borders of the Dinant Synclinorium. Courier Forschungs-Institut Senckenberg, 55, 139-164.

Gourvennec, R. 1989. Brachiopodes Spiriferida du Dévonien inférieur du Massif armoricain. SystématiquePaléobiologie-Evolution-Biostratigraphie. Biostratigraphie du Paléozoique, 9, 1-281.

Harland, W. B., Armstrong, R. L., Cox, A. V., Craig, L. E., Smith, A. G. and Smith, D. G. 1990. A geologic time scale 1989. Cambridge University Press, Cambridge. XVI+263 pp.

Jahnke, H. 1971. Fauna und Alter der Erbslochgrauwacke. (Brachiopoden und Trilobiten, Unter-Devon, Rheinisches Schiefergebirge und Harz). I-III. Göttinger Arbeiten Geologie und Paläontologie, 9, 1-105.

Kayser, E. 1889. Die Fauna des Hauptquarzits und der Zorger Schiefer des Unterharzes. Abhandlungen der preußischen geologischen Landesanstalt, Neue Folge, 1, 1-140.

Koch, C. 1881. Über die Gliederung der rheinischen Unterdevon-Schichten zwischen Taunus und Westerwald. Jahrbuch der preußischen geologischen Landes-Anstalt, 1 (für 1880), 190-242. 
Kozłowski, R. 1929. Les brachiopodes gothlandiens de la Podolie polonaise. Palaeontologia Polonica, 1, 1-254.

Krantz, F. 1857. Über ein neues bei Menzenberg aufgeschlossenes Petrefakten-Lager in den devonischen Schichten. Verhandlungen des naturwissenschaftlichen Vereins von Rheinland und Westfalen, 14, 143-165.

McKerrow, W. S. 1994. Terrane assembly in the Variscan Belt of Europe. Journal of the Czech Geological Society, 39 (1), 68.

Mittmeyer, H.-G. 1974. Zur Neufassung der Rheinischen Unterdevon-Stufen. Mainzer Geowissenschaften Mitteilungen, 3, 69-79.

Mittmeyer, H.-G. 1982. Rhenish Lower Devonian Biostratigraphy. Courier Forschungs-Institut Senckenberg, 55, 257-270.

Morzadec, P., Paris, F. and Racheboeuf, P. 1988. Lower Devonian of the Armorican Massif. Guidebook of the field meeting. International Union of Geological Sciences, Subcommission on Devonian Stratigraphy. Brest-Rennes. International Subcommission on Devonian Stratigraphy. 55 pp.

Muir-Wood, H. M. 1925. Notes on the Silurian brachiopod genera Delthyris, Uncinulina and Meristina. Annals and Magazine of Natural History, 9 (15), 83-95.

Oehlert, D.-P. 1888. Descriptions de quelques espèces dévoniennes du département de la Mayenne. Bulletin de la Société d'Études scientifiques d'Angers, 1887, 65-112.

Paproth, E. 1960. Über die Fauna der mittleren Siegener Schichten des Siegerlandes. Abhandlungen des hessischen Landesamtes für Bodenforschung, 29, 321339.

Racheboeuf, P. R. 1976. Chonetacea (Brachiopodes) du Dévonien inférieur du Bassin de Laval (Massif Armoricain). Palaeontographica, Abteilung A, 152, 1489.

Renaud, A. 1942. Le Dévonien du Synclinorium médian Brest-Laval 2. Paléontologie. Mémoires de la Société géologique et minéralogique de Bretagne, 7, 1-439.

Robardet, M., Groos-Uffernorde, H., Gandl, J. et Racheboeuf, P. R. 1991. Trilobites et ostracodes du Dévonien inférieur de la Zone d'Ossa-Morena (Espagne). Geobios, 24 (3), 333-348.

Robardet, M., Blaise, J., Bouyx, E., Gourvennec, R., Lardeux, H., Le Hérissé, A., Le Menn, J., Mélou, M., Paris, F., Plusquellec, Y., Poncet, J., Régnault, S., Rioult, M. et Weyant, M. 1993. Paléogéographie de l'Europe occidentale de l'Ordovicien au Dévonien. Bulletin de la Sociéte géologique de France, 164 (5), 683-695.

Roemer, C. F. 1844. Das Rheinische Übergangsgebirge. Eine paläontologisch-geognostiche Darstellung. Hannover. 96 pp.
Simpson, S. 1940. Das Devon der Südost-Eifel zwischen Nette und Alf. Stratigraphie und Tektonik mit einem Beitrag zur Hunsrückschiefer-Frage. Abhandlungen der senckenbergischen naturforschenden Gesellschaft, 436, $1-81$.

Smith, A. G. 1996. Some aspects of the Phanerozoic paleogeographic evolution of Europe. Zeitschrift ${ }^{\cdot}$ der deutschen geologischen Gesellschaft, 147 (2), 147-168.

Solle, G. 1953. Die Spiriferen der Gruppe arduennensisintermedius im rheinischen Devon. Abhandlungen des hessischen Landesamtes für Bodenforschung, 5, 1-156.

Solle, G. 1960. Synsedimentäre Bruchtektonik im SüdwestTeil der rheinischen Geosynklinale im epirogenen Stadium. Notizblatt des hessischen Landesamtes für Bodenforschung, 88, 343-360.

Solle, G. 1970. Die Hunsrück-Insel im oberen Unterdevon. Notizblatt des hessischen Landesamtes für Bodenforschung, 98, 50-80.

Sowerby, J. de C. 1839. In: The Silurian System, Founded on a Series of Geological Researches in the Counties of Salop, Hereford, Radnor, Montgomery, Caermarthen, Brecon, Pembroke, Monmouth, Gloucester, Worcester, and Stafford; With Descriptions of the Coal-fields and Overlying Formations. (Aut. R. I. Murchison). John Murray, London. xxxii+768 pp.

Steininger, J. 1853. Geognostische Beschreibung der Eifel. F. Lintz, Trier. 144 pp.

Straw, S. H. 1933. The Fauna of the Paleozoic Rocks of the Little Missenden Boring. Summ. Progr. Geol. Surv. U. K., 2, 112-132.

Valenzuela Ríos, J. I. 1984. Estudio geológico de un sector de las Cadenas Ibericas Orientales entre Minas Tierga, Mesones y Nigüella (Zaragoza). Tesis de Licenciatura, Universidad de Zaragoza. 132 pp. [Unpublished.]

Valenzuela Ríos, J. I. 1989. El Paleozoico de Nigüella (nota preliminar). Azara, 1, 35-43.

Vandercammen, A. 1963. Spiriferidae du Dévonien de la Belgique. Mémoires de l'Institut Royal des Sciences naturelles de Belgique, 150, 1-179.

Weddige, K. (Ed.) 1996. Devon-Korrelationstabelle. Senckenbergiana lethaea, 76 (1/2), 267-286.

Zeiler, F. 1857. Versteinerungen der älteren Rheinischen Grauwacke. Verhandlungen des naturhistorischen Vereins der preußischen Rheinlande, 14, 45-51.

Ziegler, P. 1988. Laurussia - the Old Red Continent. In: Devonian of the World. (Proceedings of the 2nd International Symposium on the Devonian System, Calgary 1987). (Eds. N. J. McMillan, A. F. Embry and D. J. Glass). Canadian Society of Petroleum Geologists Memoir, 14 (1), 15-48. 